\title{
Geochemistry of organic carbon in surface sediments of a summer hypoxic region in the coastal waters of northern Shandong Peninsula
}

\author{
Bo Yang ${ }^{\mathrm{a}, \mathrm{b}}$, Xuelu Gao ${ }^{\mathrm{a}, \mathrm{b}, *}$, Qianguo Xing ${ }^{\mathrm{a}}$ \\ ${ }^{\text {a }}$ CAS Key Laboratory of Coastal Environmental Processes and Ecological Remediation, Yantai Institute of Coastal Zone Research, Chinese Academy of Sciences, Yantai, \\ Shandong 264003, China \\ ${ }^{\mathrm{b}}$ University of Chinese Academy of Sciences, Beijing 100049, China
}

\section{A R T I C L E I N F O}

\section{Keywords:}

Sediment analysis

Sedimentary organic matter

Stable carbon and nitrogen isotopes

Coastal environment

Spatiotemporal distribution

Shelf sea

\begin{abstract}
A B S T R A C T
The geochemistry of sedimentary organic matter (SOM) in coastal areas is complex due to its multiple sources and intricate hydrological features. In this study, the biogenic element concentrations and stable carbon $\left(\delta^{13} \mathrm{C}\right)$ and nitrogen $\left(\delta^{15} \mathrm{~N}\right)$ isotopic compositions in the coastal surface sediments of northern Shandong Peninsula, along with some parameters related to water quality, were analyzed to investigate the temporal-spatial variations in SOM and the processes that control its distribution. The results revealed that marine autogenous organic matter is a major contributor to SOM, accounting for $75.4 \pm 3.3 \%, 60.8 \pm 6.6 \%$ and $67.4 \pm 10.3 \%$ in August and November 2015 and March 2016, respectively. In summer, TOC and TN concentrations were significantly higher than those in autumn and spring. The relatively high abundances of SOM were found in the offshore areas in summer and spring, which was contrary to those in autumn. Riverine discharge, nutrients, primary productivity and dissolved oxygen (DO) dynamics could all influence the composition and contents of SOM in different seasons. In summer, high primary productivity and hypoxia condition led to high SOM values. In comparison, SOM contents were relatively low due to sufficient DO in bottom water in autumn and spring. Dissolved nutrients in seawater could affect the accumulation of autogenous organic matter by impacting upon primary production. In summer, nitrate in surface water had the most obvious effects on autogenous organic carbon (AOC) and may be the principal factor of limiting the growth of phytoplankton. In autumn, nitrate as well as dissolved silicate had more effects on AOC storage. However, phosphate had the most obvious influence on AOC storage in spring.
\end{abstract}

\section{Introduction}

As a main connection between the continents and the oceans, coastal zones and estuaries trap significant quantities of allochthonous and autochthonous organic matter (OM) through a series of complex physical, chemical and biological processes during transport, deposition and burial (Thornton and Mcmanus, 1994), resulting in the accumulation of more than $90 \%$ of the global marine organic carbon in continental margin sediments (Emerson and Hedges, 1988). Characterizing the distribution and sources of sedimentary organic matter (SOM) can provide a better understanding of the mechanisms controlling the dispersal, preservation and fate of marine organic matter (Gordon and Goñi, 2003).

The proxies of total organic carbon (TOC) and total nitrogen (TN), including their molar ratios (TOC/TN or $\mathrm{C} / \mathrm{N})$ and stable isotopes $\left(\delta^{13} \mathrm{C}\right.$ and $\delta^{15} \mathrm{~N}$ ) have been used extensively in the identification of the sources (allochthonous and autochthonous sources) and the cycles of OM in diffident aquatic environments (Kristensen et al., 2008), such as the Changjiang Estuary in China (Liu et al., 2006), the Cochin Estuary in India (Gireeshkumar et al., 2013), the coastal Bohai Bay in China (Gao et al., 2012; Liu et al., 2015), the Winyah Bay in the United States (Goñi et al., 2003), and the Harbor of Naples in Italy (Rumolo et al., 2011).

The Yellow Sea (YS) is a semi-enclosed shallow sea of the northwestern Pacific boarded by the Bohai Sea in the west, which has offshore characteristics. No large river discharges directly into the YS. However, parts of the Yellow River-derived fine-grained sediments could resuspend, be transported by the longshore current from the Bohai Sea, and deposit in the YS over a long-time scale (Alexander et al., 1991; Martin et al., 1993; Bi et al., 2011). The north coast of the

\footnotetext{
* Correspondence to: CAS Key Laboratory of Coastal Zone Environmental Processes and Ecological Remediation, Yantai Institute of Coastal Zone Research, Chinese Academy of Sciences, 17 Chunhui Road, Laishan District, Yantai, Shandong 264003, China.

E-mail address: xlgao@yic.ac.cn (X. Gao).
} 
Shandong Peninsula, located in the North Yellow Sea (NYS), with a history of over 60 years of marine raft culture (mainly including scallop, mussel and seaweed) in the coastal waters, is one of the fastest developing areas in China. Millions of people live along the north coast of the Shandong Peninsula. Over the last two decades, due to the rapid economic and industrial development in this region, copious amounts of organic and inorganic pollutants have been discharged into its coastal waters. It is estimated that approximately 150 tons of phosphorus and 1910 tons of nitrogen are released into the coastal areas near Yantai from sewage discharge every year (Han and Liu, 2014), resulting in serious environmental issues. For example, hypoxia in the bottom water occurs in summer. Algae blooms frequently appear from spring to autumn (Zhai et al., 2014). These changes have the potential to alter the nature and content of SOM (Owen and Lee, 2004). There are many reports on the ecological aspects of the NYS (Zhang et al., 2013; Zhai et al., 2014; Chen et al., 2015). However, detailed information on the temporal-spatial variability of SOM distribution in the coastal waters of northern Shandong Peninsula is scarcely documented. Thus, the main objectives of this study, based on the hydrogeological investigation of this region and multiple geochemical data obtained from the analysis of its surface sediments, including TOC, TN, grain size, $\delta^{13} \mathrm{C}$ and $\delta^{15} \mathrm{~N}$, were to (1) explore the spatial-temporal variations in organic carbon and nitrogen, (2) determine the factors controlling the SOM distribution and accumulation, and (3) assess the relative contribution of allochthonous and autochthonous sources of SOM.

\section{Materials and methods}

\subsection{Study area}

The research area, which lies in the coastal waters of northern Shandong Peninsula (Fig. 1), along with the Yantai-Weihai coastline, is one of the intensively maricultured areas in China with a maximum water depth of about $22 \mathrm{~m}$. There are 7 small rivers flowing into the coastal waters (i.e. Xin'an River, Yu'niao River, Qinshui River, Han River, Guang River, Nian River and Yangting River). The water salinity ranges from 30 to 32, and the temperature varies from $8{ }^{\circ} \mathrm{C}$ (February) to $26^{\circ} \mathrm{C}$ (September). Seasonal hypoxia phenomenon in bottom water usually occurs in this study area in summer.

\subsection{Sampling location}

The field data and samples used in this study were obtained through three cruises being conducted in August (summer) 2015 and November (late autumn) 2015 and March (early spring) 2016. As shown in Fig. 1, a total of 26 stations were covered in six transects. Water and surface 0-2 cm sediment samples were collected using a Niskin sampler and a Van Veen style stainless steel grab sampler. Two layers of water samples were obtained, i.e. surface ( $1 \mathrm{~m}$ under the sea surface) and bottom ( $1 \mathrm{~m}$ above the seabed) waters. After collection, about $100 \mathrm{ml}$ of each water sample were filtered through pre-acid-cleaned and pre-combusted
( $500{ }^{\circ} \mathrm{C}$ for $5 \mathrm{~h}$ ), $0.7 \mu \mathrm{m}$ pore size Whatman GF/F filters. The filtrates were gathered in acid-cleaned polyethylene bottles $(100 \mathrm{ml})$ and stored at $-20^{\circ} \mathrm{C}$ until further analysis in the laboratory. The sediment samples were homogenized and placed into sterile polyethylene bags, and stored at $-20^{\circ} \mathrm{C}$ until further analysis.

Seawater temperature, salinity and dissolved oxygen (DO) values were continuously determined using a SeaBird 911 plus CTD equipped with a DO sensor (membrane electrode) at precision of $\pm 0.01{ }^{\circ} \mathrm{C}$ (temperature), \pm 0.01 (salinity) and $\pm 0.01 \mathrm{mg} \mathrm{l}^{-1}$ (DO).

\subsection{Sample preparation and analysis}

The values of seawater nitrate $\left(\mathrm{NO}_{3}{ }^{-}\right)$, nitrite $\left(\mathrm{NO}_{2}{ }^{-}\right)$, ammonium $\left(\mathrm{NH}_{4}{ }^{+}\right)$, dissolved inorganic phosphorus $\left(\mathrm{PO}_{4}{ }^{3-}\right)$ and dissolved inorganic silicate (DSi) were measured with a Skalar nutrient autoanalyzer using the standard colorimetric methods according to AydinOnen et al. (2012). The detection limits were 0.02, 0.02, 0.03, 0.01 and $0.02 \mu \mathrm{moll}^{-1}$ for $\mathrm{NO}_{3}{ }^{-}, \mathrm{NO}_{2}{ }^{-}, \mathrm{NH}_{4}{ }^{+}, \mathrm{PO}_{4}{ }^{3-}$ and $\mathrm{DSi}$, respectively. The relative standard deviations (RSD) of both repeatability and reproducibility for nutrient analysis were less than $5 \%$.

A small portion of each sediment sample was used for grain-size analysis, and another portion was freeze-dried, homogenized and ground in an agate mortar for the analyses of TN, TOC, $\delta^{13} \mathrm{C}$ and $\delta^{15} \mathrm{~N}$. The sample grain-size was determined using a laser particle size analyzer (Mastersizer 2000, Malven Instruments Ltd., UK) capable of analyzing particle sizes between $0.02 \mu \mathrm{m}$ and $2000 \mu \mathrm{m}$ after removing $\mathrm{OM}$ and carbonates with $15 \% \mathrm{H}_{2} \mathrm{O}_{2}$ and $4 \mathrm{moll}^{-1} \mathrm{HCl}$ (Qiao et al., 2010). The particle size data were classified as $<4 \mu \mathrm{m}$ for clay, 4-63 $\mu \mathrm{m}$ for silt, and $>63 \mu \mathrm{m}$ for sand.

Approximately $150 \mathrm{mg}$ of each sample were weighed into $5 \times 8 \mathrm{~mm}$ tin capsules for the measurement of total carbon and TN via high temperature combustion on an Elementar vario MACRO cube CHNS analyzer. Total inorganic carbon (TIC) analysis was carried out on a Shimadzu TOC- $\mathrm{V}_{\mathrm{CPH}} / \mathrm{SSM}-5000 \mathrm{~A}$ analyzer. TOC in sediment was obtained by subtracting TIC from total carbon. The precision was \pm $0.02 \% \mathrm{C}$ and $\pm 0.003 \%$ TN by dry weight $(\mathrm{n}=5)$. For isotope analysis, carbonates in the samples were removed with $0.5 \mathrm{moll}^{-1} \mathrm{HCl}$, and then the samples were rinsed with deionized water to neutral condition before drying overnight at $60{ }^{\circ} \mathrm{C}$ (Huon et al., 2002; Hu et al., 2006). Approximately $50.0 \mathrm{mg}$ and $8.0 \mathrm{mg}$ carbonate-free samples were accurately weighed for the measurement of $\delta^{13} \mathrm{C}$ and $\delta^{15} \mathrm{~N}$, respectively, with a Finnigan DELTA ${ }^{\text {plus }}$ XL isotope ratio mass spectrometer, and the results were expressed in $\delta$ notation as the deviation from standard reference material in parts per mil (\%o):

$\delta(\%)=\left(R_{\text {sample }} / R_{\text {reference }}-1\right) \times 1000$

where $\delta(\%)$ stands for $\delta^{13} \mathrm{C}$ or $\delta^{15} \mathrm{~N}$, and $\mathrm{R}_{\text {sample }}$ and $\mathrm{R}_{\text {standard }}$ are the heavy to light isotopic ratios (i.e. ${ }^{13} \mathrm{C} /{ }^{12} \mathrm{C}$ and ${ }^{15} \mathrm{~N} /{ }^{14} \mathrm{~N}$ ) of the sample and reference, respectively. For $\delta^{13} \mathrm{C}$, the reference is Peedee Belemnite (PDB), and for $\delta^{15} \mathrm{~N}$, it is atmospheric nitrogen. The samples were run in duplicate and the analytical precision was $\pm 0.2 \%$ for $\delta^{13} \mathrm{C}$ and \pm

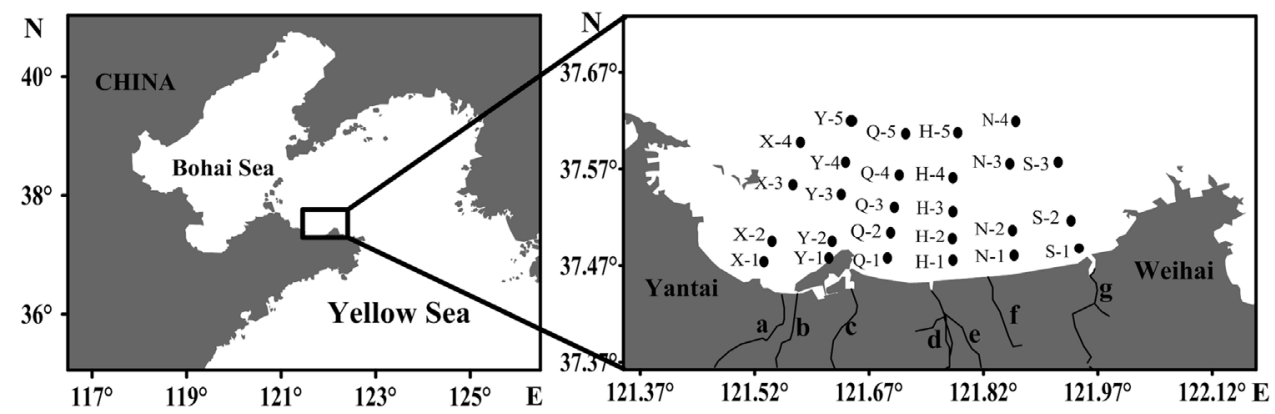

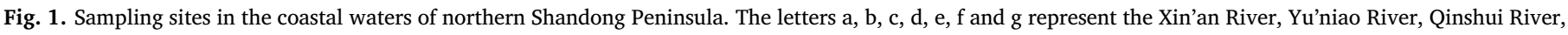
Hai River, Guang River, Nian River and Yangting River, respectively. 
Table 1

General information of temperature and salinity in the coastal waters of northern Shandong Peninsula.

\begin{tabular}{|c|c|c|c|c|c|}
\hline \multirow[t]{2}{*}{ Season } & \multirow[t]{2}{*}{ Sampling depth } & \multicolumn{2}{|c|}{ Temperature $\left({ }^{\circ} \mathrm{C}\right)$} & \multicolumn{2}{|l|}{ Salinity } \\
\hline & & Range & Mean \pm SD & Range & Mean \pm SD \\
\hline \multirow[t]{2}{*}{ Summer } & Surface & $25.4-27.6$ & $26.9 \pm 0.6$ & $30.6-31.0$ & $30.8 \pm 0.1$ \\
\hline & Bottom & $21.0-24.9$ & $22.7 \pm 0.1$ & $30.8-31.3$ & $31.1 \pm 0.1$ \\
\hline \multirow[t]{2}{*}{ Autumn } & Surface & $8.0-14.4$ & $10.6 \pm 2.7$ & $27.4-31.2$ & $29.6 \pm 1.1$ \\
\hline & Bottom & $8.1-14.1$ & $10.6 \pm 2.6$ & $30.8-31.7$ & $31.2 \pm 0.3$ \\
\hline \multirow[t]{2}{*}{ Spring } & Surface & $2.8-6.2$ & $4.4 \pm 0.9$ & $28.3-31.9$ & $30.0 \pm 1.0$ \\
\hline & Bottom & $2.5-4.0$ & $3.1 \pm 0.4$ & $31.6-32.1$ & $31.8 \pm 0.1$ \\
\hline
\end{tabular}

$0.3 \%$ for $\delta^{15} \mathrm{~N}$.

\subsection{Data processing}

Statistical analyses were performed with the Origin 8.0. Contour maps were generated by the Surfer 12 (Golden Software LLC) using the kriging method. Principal component analysis (PCA) and Pearson's correlation analysis were performed by SPSS 19.0 software to examine the relationships among SOM related parameters (e.g. TOC, TN, C/N, $\delta^{13} \mathrm{C}, \delta^{15} \mathrm{~N}$, sand, clay and silt).

\section{Results and discussion}

\subsection{Hydrographic features of water environment}

Complex hydrographic conditions occurred during the study period (Table 1), which may influence the transport and concentration of biogenic elements. Overall, salinity was relatively stable at around 30, while the temperature ranged broadly from $2.5^{\circ} \mathrm{C}$ to $27.6{ }^{\circ} \mathrm{C}$. In summer, the seasonal thermal stratification in water formed, and temperature exhibited significant vertical variations, with the values of $26.9 \pm 0.6^{\circ} \mathrm{C}$ (mean $\pm \mathrm{SD}$ ) and $22.7 \pm 0.1{ }^{\circ} \mathrm{C}$ in surface and bottom water, respectively. However, in late autumn and early spring, the thermal stratification disappeared and the water column became vertically well-mixed, displaying uniform temperature.

The concentrations of nutrients and DO in water are shown in Table 2. In surface water, the dissolved inorganic nitrogen (DIN $=\mathrm{NO}_{2}$ $+\mathrm{NO}_{3}^{-}+\mathrm{NH}_{4}^{+}$) values were $1.65 \pm 0.75 \mu \mathrm{mol} 1^{-1}$ in summer, lower than in autumn $\left(3.38 \pm 2.15 \mu \mathrm{moll}^{-1}\right)$ and spring $\left(11.59 \pm 7.60 \mu \mathrm{moll}^{-1}\right)$. Unlike DIN, the high $\mathrm{PO}_{4}{ }^{3-}$ and DSi values appeared in autumn with the mean of $0.28 \pm 0.03 \mu \mathrm{moll}^{-1}$ and $4.30 \pm 2.90 \mu \mathrm{moll}^{-1}$, respectively, while low values occurred in spring with the average of $0.06 \pm 0.08 \mu \mathrm{moll}^{-1}$ and $2.57 \pm 1.62 \mu \mathrm{mol}^{-1}$. Meanwhile, the high and low DO values appeared in spring (mean $341.1 \pm 25.9 \mu \mathrm{moll}^{-1}$ ) and summer (mean $199.4 \pm 5.6 \mu \mathrm{mol}^{-1}$ ). In bottom water, the concentrations of DIN, $\mathrm{PO}_{4}{ }^{3-}, \mathrm{DSi}$ and DO were similar to those of the surface water in autumn and spring. However, in summer, the values of DIN, $\mathrm{PO}_{4}{ }^{3-}$ and DSi in bottom water were about 1.27-3.99 folds of those in surface water, while DO were only $37.8 \%$ of the surface water, which could be attributed to the high primary production and decomposition processes of SOM. In summer, phytoplankton grows more vigorously than in other seasons with more nutrients being absorbed (Wang et al., 2003), resulting in relatively low nutrient values in surface water. Meanwhile, some SOM are decomposed (Andrieux and Aminot, 1997) with the consumption of DO and the release of nutrients (Wang et al., 1999). In addition, the vertical exchange of surface and bottom waters is hindered due to density stratification, resulting in high nutrients and low DO values in bottom water.

\subsection{TOC and TN in surface sediments}

Tables 3 and 4 show the TOC and TN values and particle size composition of the surface sediment samples, and their corresponding spatial variations are shown in Fig. 2. As the basic environmental parameters, TOC and TN could reflect the enrichment and bulk composition of OM in sediment and affect the nutrient cycle in overlying water. In summer, TOC contents ranged broadly from $0.34 \%$ to $0.90 \%$ with an average of $0.68 \pm 0.14 \%$; in comparison, its contents were relatively low in autumn and spring, with the values varying from $0.38 \%$ to $0.78 \%$ (mean $0.50 \pm 0.09 \%$ ) and $0.13-0.58 \%$ (mean $0.44 \pm 0.10 \%$ ). Similar to TOC, TN contents also showed a wide range of $0.043-0.103 \%$ (mean $0.083 \pm 0.016 \%$ ), $0.041-0.097 \%$ (mean $0.058 \pm 0.012 \%$ ) and $0.014-0.075 \%$ (mean $0.053 \pm 0.014 \%$ ) in summer, autumn and spring, respectively. In general, TN can be divided into two components in sediments, i.e. organic nitrogen (ON) and inorganic nitrogen (IN), and the plot of TOC versus TN can be used to assess the contribution of absorbed IN to SOM based on a positive TN intercept (Goñi et al., 1997; Schubert and Calvert, 2001). In this study, a significant linear correlation between TOC and TN was found with the correlation coefficient $\left(\mathrm{R}^{2}\right)$ of $0.902(P<0.001)$, $0.892(P<0.001)$ and $0.930(P<0.001)$ in summer, autumn and spring, respectively (Fig. 3a, b and c). In summer, the intercept of TOC versus TN was $0.0122 \%$, indicating the existence of IN in TN; however, the intercepts were close to zero in autumn $(-0.0024 \%)$ and spring $(-0.0063 \%)$, indicating that TN is predominantly of organic origin (Goñi et al., 2003) in those two seasons. Compared with other studies (Table 4), TOC values in this study in late autumn and spring were comparable to those found in the East China Sea shelf (Zhou et al., 2018) and the Yellow Sea (Hu et al., 2013), but higher than those of the Jiaozhou Bay (Dai et al., 2007) and the Bohai Bay (Hu et al., 2009). Like TOC, the TN values in this study were comparable to the Yellow Sea (Hu et al., 2013) in winter, but lower than those of the East China Sea shelf (Zhou et al., 2018) and the Pearl River estuary (Liu et al., 2012).

As can be seen from Fig. 2a, b, and c, the spatial patterns of TOC in the surface sediments in summer and spring were similar to some extent, with relatively low values observed near to the river mouths, such

Table 2

Dissolved nutrients and oxygen concentrations in the coastal waters of northern Shandong Peninsula $\left(\mu \mathrm{mol} 1^{-1}\right)$.

\begin{tabular}{|c|c|c|c|c|c|c|c|c|}
\hline Season & Depth & & $\mathrm{NO}_{2}^{-}$ & $\mathrm{NO}_{3}^{-}$ & $\mathrm{NH}_{4}^{+}$ & $\mathrm{PO}_{4}{ }^{3-}$ & $\mathrm{DSi}$ & DO \\
\hline \multirow[t]{4}{*}{ Summer } & Surface & Range & $0.04-0.10$ & $0.44-3.16$ & $0.01-0.92$ & $0.20-0.29$ & $0.22-5.30$ & $188.0-208.8$ \\
\hline & & Mean \pm SD & $0.06 \pm 0.02$ & $1.23 \pm 0.70$ & $0.36 \pm 0.22$ & $0.26 \pm 0.02$ & $2.58 \pm 1.77$ & $199.4 \pm 5.6$ \\
\hline & Bottom & Range & $0.19-0.65$ & $0.01-4.29$ & $3.40-9.16$ & $0.25-0.64$ & $4.56-11.70$ & $47.2-108.8$ \\
\hline & & Mean $\pm S D$ & $0.37 \pm 0.11$ & $1.12 \pm 1.11$ & $5.62 \pm 1.47$ & $0.33 \pm 0.10$ & $9.08 \pm 1.92$ & $77.1 \pm 16.6$ \\
\hline \multirow[t]{4}{*}{ Autumn } & Surface & Range & $0.04-0.32$ & $0.13-6.67$ & $0.28-6.44$ & $0.23-0.33$ & $0.93-11.22$ & $194.3-255.6$ \\
\hline & & Mean \pm SD & $0.11 \pm 0.06$ & $1.98 \pm 1.52$ & $1.29 \pm 1.56$ & $0.28 \pm 0.03$ & $4.30 \pm 2.90$ & $228.5 \pm 18.3$ \\
\hline & Bottom & Range & $0.05-0.28$ & $0.14-8.98$ & $0.07-4.56$ & $0.25-0.33$ & $0.83-10.92$ & $197.8-235.8$ \\
\hline & & Mean $\pm S D$ & $0.12 \pm 0.06$ & $2.14 \pm 1.86$ & $1.43 \pm 1.36$ & $0.28 \pm 0.02$ & $4.69 \pm 2.95$ & $220.2 \pm 14.8$ \\
\hline \multirow[t]{4}{*}{ Spring } & Surface & Range & $0.18-0.68$ & $2.94-16.01$ & $0.25-17.16$ & $0.01-0.30$ & $0.33-5.81$ & $297.5-380.1$ \\
\hline & & Mean $\pm S D$ & $0.30 \pm 0.13$ & $7.53 \pm 3.91$ & $3.76 \pm 4.38$ & $0.06 \pm 0.08$ & $2.57 \pm 1.62$ & $341.1 \pm 25.9$ \\
\hline & Bottom & Range & $0.15-0.86$ & $3.02-13.55$ & $0.47-9.66$ & $0.01-0.35$ & $0.02-5.44$ & $293.3-349.4$ \\
\hline & & Mean $\pm S D$ & $0.29 \pm 0.15$ & $7.04 \pm 3.65$ & $2.70 \pm 1.96$ & $0.05 \pm 0.09$ & $2.40 \pm 1.47$ & $308.5 \pm 13.0$ \\
\hline
\end{tabular}


Table 3

Summary information about the clay, silt and sand fractions of sediments, $f^{\prime}$, and AOC and Ter-OC contents in different seasons (\%).

\begin{tabular}{|c|c|c|c|c|c|c|c|}
\hline Season & & Clay & Silt & Sand & $f^{\prime}$ & $\mathrm{AOC}$ & Ter-OC \\
\hline \multirow[t]{2}{*}{ Summer } & Range & $7.3-21.0$ & $47.3-80.4$ & $2.2-42.8$ & $68.3-81.2$ & $0.26-0.67$ & $0.09-0.23$ \\
\hline & Mean $\pm S D$ & $14.5 \pm 3.5$ & $65.4 \pm 8.4$ & $20.1 \pm 11.0$ & $75.4 \pm 3.3$ & $0.52 \pm 0.12$ & $0.17 \pm 0.04$ \\
\hline \multirow[t]{2}{*}{ Autumn } & Range & 5.9-21.7 & $21.9-77.0$ & $5.2-72.2$ & $48.7-71.9$ & $0.20-0.51$ & $0.12-0.27$ \\
\hline & Mean $\pm S D$ & $16.4 \pm 4.4$ & $64.2 \pm 11.5$ & $19.4 \pm 14.5$ & $60.8 \pm 6.6$ & $0.30 \pm 0.07$ & $0.19 \pm 0.04$ \\
\hline \multirow[t]{2}{*}{ Spring } & Range & $0.6-23.5$ & $1.2-71.9$ & $6.8-98.2$ & $37.5-77.8$ & $0.05-0.44$ & $0.08-0.20$ \\
\hline & Mean $\pm S D$ & $15.4 \pm 4.5$ & $63.8 \pm 13.7$ & $20.8 \pm 17.2$ & $67.4 \pm 10.3$ & $0.30 \pm 0.09$ & $0.14 \pm 0.03$ \\
\hline
\end{tabular}

Table 4

Comparison of TOC, TN, TOC/TN ratios, $\delta^{13} \mathrm{C}$ and $\delta^{15} \mathrm{~N}$ in surface sediments of the coastal waters of northern Shandong Peninsula with related data.

\begin{tabular}{|c|c|c|c|c|c|c|c|c|}
\hline Location & Sampling time & & TOC (\%) & TN (\%) & $\mathrm{TOC} / \mathrm{TN}$ & $\delta^{13} \mathrm{C}(\%)$ & $\delta^{15} \mathrm{~N}(\% 0)$ & Reference \\
\hline \multirow{6}{*}{$\begin{array}{l}\text { Coastal waters of northern } \\
\text { Shandong Peninsula }\end{array}$} & Aug., 2015 & Range & $0.34-0.90$ & $0.043-0.103$ & $7.05-9.07$ & -22.56 to -21.72 & $5.55-8.51$ & This study \\
\hline & & Mean & $0.68 \pm 0.14$ & $0.083 \pm 0.016$ & $8.20 \pm 0.55$ & $-22.10 \pm 0.21$ & $6.69 \pm 0.71$ & \\
\hline & Nov., 2015 & Range & $0.38-0.78$ & $0.041-0.097$ & $7.77-9.59$ & -23.84 to -22.33 & $5.12-6.79$ & This study \\
\hline & & Mean & $0.50 \pm 0.09$ & $0.058 \pm 0.012$ & $8.66 \pm 0.54$ & $-23.05 \pm 0.43$ & $5.51 \pm 0.33$ & \\
\hline & Mar., 2016 & Range & $0.13-0.58$ & $0.014-0.075$ & $7.26-13.69$ & -24.56 to -21.94 & $4.95-5.95$ & This study \\
\hline & & Mean & $0.44 \pm 0.10$ & $0.053 \pm 0.014$ & $8.47 \pm 1.20$ & $-22.62 \pm 0.67$ & $5.43 \pm 0.24$ & \\
\hline \multirow[t]{2}{*}{ Yellow Sea } & $2007-2008$ & Range & $0.08-1.07$ & $0.02-0.103$ & $5.0-14.0$ & -21.26 to -21.26 & na & Hu et al. (2013) \\
\hline & & Mean & $0.46 \pm 0.25$ & $0.06 \pm 0.03$ & 8.0 & na & na & \\
\hline \multirow[t]{2}{*}{ Bohai Bay } & 2006 & Range & $0.04-0.69$ & $0.01-0.09$ & $3.3-7.7$ & -23.9 to -21.7 & na & Hu et al. (2009) \\
\hline & & Mean & $0.38 \pm 0.17$ & na & na & na & na & \\
\hline Sishili Bay & Nov., 2008 & Range & $0.17-1.33$ & $0.02-0.104$ & 7.9-10.1 & -22.7 to -21.6 & $5.4-6.5$ & Liu et al. (2012) \\
\hline Pearl River Estuary & Mar., 2005 & Range & $0.48-1.60$ & $0.09-0.2$ & $8.50-15.32$ & na & na & \\
\hline \multirow[t]{2}{*}{ Jiaozhou Bay } & Sep. 2003 & Range & $0.07-0.45$ & $0.016-0.048$ & na & na & na & Dai et al. (2007) \\
\hline & & Mean & 0.38 & 0.032 & na & na & na & \\
\hline \multirow[t]{2}{*}{ Changjiang Estuary and adjacent sea } & $2006-2007$ & Range & $0.19-0.92$ & na & na & -23.8 to -20.7 & na & Yang et al. (2015) \\
\hline & & Mean & 0.50 & na & na & na & na & \\
\hline Coastal areas of the East China Sea & Jun., 2010 & Range & na & na & na & -21.8 to -20.7 & na & \\
\hline \multirow{4}{*}{ East China Sea shelf } & May to Jun., 2014 & Range & $0.15-0.75$ & $0.022-0.151$ & $4.69-9.12$ & -22.08 to -19.99 & $3.67-6.28$ & Zhou et al. (2018) \\
\hline & & Mean & 0.54 & 0.096 & 6.7 & -21.35 & 4.6 & \\
\hline & Oct. to Nov., 2014 & Range & $0.17-0.75$ & $0.027-0.137$ & $4.78-8.89$ & -21.97 to -20.10 & $4.60-6.13$ & \\
\hline & & Mean & 0.43 & 0.077 & 6.7 & -21.00 & 5.3 & \\
\hline
\end{tabular}

na: not available.

as sites $\mathrm{H} 1(0.50 \%)$, sites $\mathrm{H} 2(0.47 \%)$ in summer and sites Y-1 $(0.13 \%)$ and sites S-1 $(0.19 \%)$ in spring. In autumn, the spatial pattern of TOC was different from that in summer and spring with a seaward decreasing trend. Like the spatial distribution of TOC, relatively low TN values occurred in the inshore areas in summer and spring, while low TN values appeared in the offshore areas in autumn. Generally, SOM is mainly derived from the watershed or in situ production. Eutrophication, urban/industrial/agricultural pollution and sedimentary characteristics can affect SOM through biogeochemical processes such as nutrient recycling. In summer, appropriate temperature and sunlight provide suitable conditions for phytoplankton breeding, thus increasing the OM values in sediments to some extent. However, it is not easy for OM to deposit in the places near to river mouths due to complicated hydrodynamics conditions. Moreover, primary production is limited due to high turbidity in the places near to river mouths, resulting in low phytoplankton-derived OM deposition rates. Thus, relatively low OM concentrations were found in the places near to river mouths in summer and spring. This phenomenon is also observed in other estuaries, e.g. the Yangtze, Pearl, and Ayeyarwady Rivers (Zhang et al., 1990; Hu et al., 2006; Ramaswamy et al., 2008).

Sediment grain size is an important factor influencing the geochemical behaviors of SOM (Keil et al., 1998), and most OM can absorb to the surfaces of clay-size mineral grains (Keil et al., 1994, 1998; Ransom et al., 1998). In this research area, silt was the dominant fraction at most sampling stations (except site Q-1), with the average accounting for $65.4 \pm 8.4 \%$ in summer, $64.2 \pm 11.5 \%$ in autumn and $63.8 \pm 13.7 \%$ in spring (Table 3). As for spatial variations (Fig. 2), fine-grained sediments (silt and clay) were mainly distributed in the offshore waters (Fig. $2 \mathrm{~g}$ to 1 ), whereas the coarser deposits mainly occurred in the places near to river mouths (especially at site Q-1)
(Fig. 2m, $\mathrm{n}$ and o). In summer, a significant linear correlation between fine-grained sediments (clay and silt) and either of TOC and TN was found with the $\mathrm{R}^{2}$ of $0.500(0.01<P<0.05)$ and 0.558 $(0.01<P<0.05)$, respectively (Fig. $3 \mathrm{~d}$ and g), suggesting the high accumulation of $\mathrm{OM}$ in fine fraction of sediment. However, there was no significant correlation between fine-grained sediments and either of TOC and TN $(P>0.05$, Fig. 3e, f, h and i) in autumn and spring, which could be attributed to the decomposition of SOM and complex hydrodynamic conditions in two seasons.

\subsection{Sources of organic matter in surface sediments}

The $\delta^{13} \mathrm{C}, \delta^{15} \mathrm{~N}$ and TOC/TN ratios could identify the sources (allochthonous and autochthonous sources) and the cycle of OM in aquatic environments (Kao and Liu, 2000). In this study, the general information of TOC/TN ratios, $\delta^{13} \mathrm{C}$ and $\delta^{15} \mathrm{~N}$ is summarized in Table 4 and their corresponding spatial variations are shown in Fig. 5.

\subsubsection{TOC/TN ratios}

The TOC/TN ratios have been widely used for source identification of bulk SOM in aquatic ecosystems (Gao et al., 2012; Gireeshkumar et al., 2013). Generally, terrestrial organic matter has TOC/TN of $>15$ (Meyers, 1997). As an indicator of sedimentary processes and pathways of particulate substances, suspended particulate matter is the main source of bottom sediments. The average molar ratio of principal elements in marine plankton is $106 \mathrm{C} / 16 \mathrm{~N}$, i.e. $\mathrm{C} / \mathrm{N}=6.625$ (Redfield et al., 1963). In the western North Pacific marginal seas, the organic component of the particulate matter was reported to have the average molar ratio of $\mathrm{C} / \mathrm{N}=7.69$ (Chen et al., 1996), and its value is close to $8.8(103.1 / 11.7)$ by adding in more data that obtained in the outer 

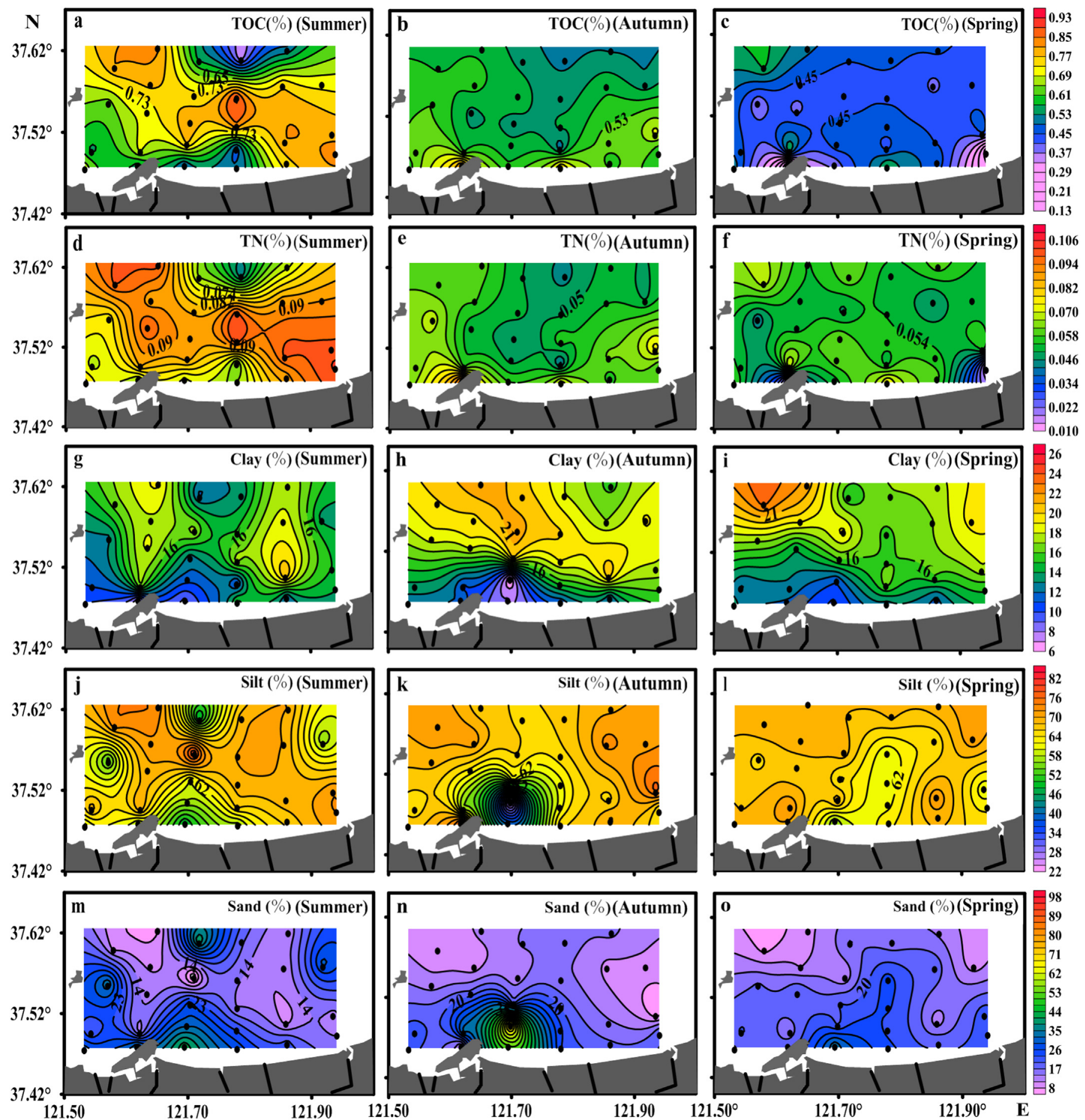

Fig. 2. Spatial distribution of TOC, TN and clay, silt and sand sediment grain sizes in surface sediments in the coastal waters of northern Shandong Peninsula.

estuaries (salinity $>25$ ) and river plumes for 73 rivers in SE mainland of China, Taiwan and SE Asia (Pan et al., 2015). As shown in Table 4, the TOC/TN ratios varied from 7.05 to 9.07 (mean $8.20 \pm 0.55$ ), 7.77-9.59 (mean $8.66 \pm 0.54$ ) and 7.26-13.69 (mean 8.47 \pm 1.20 ) in summer, autumn and spring, respectively, suggesting the mixed contribution from both marine and terrestrial origins. Compared with other studies (Table 4), the observed TOC/TN ratios in this study were comparable to those found in the coastal areas of the Yellow Sea $\mathrm{Hu}$ et al., 2013), but higher than those of the East China Sea shelf (Zhou et al., 2018) and the Bohai Bay (Hu et al., 2009). As shown in Fig. 5a, b and c, the TOC/TN ratios had seaward increasing trends in summer and spring, which were different from those in autumn. Among the sampling stations, the highest value was recorded at site S-1 near to the Yangting river mouth in spring, which was consistent with the lowest TOC and TN contents and coarse-grained sediment, indicative of the impact of land-derived input.

In general, mineralization and oxidation can all impact the TOC/TN ratios as a source indicator for OM (Andrews et al., 1998; Kuwae et al., 2007). For example, early diagenesis could increase the TOC/TN ratios. However, sometimes, TOC/TN ratios tend to decrease due to the release of $\mathrm{CO}_{2}$ or $\mathrm{CH}_{4}$ as degradation products, ammonia preservation and the addition of microbially-associated nitrogen. Moreover, organic-rich 

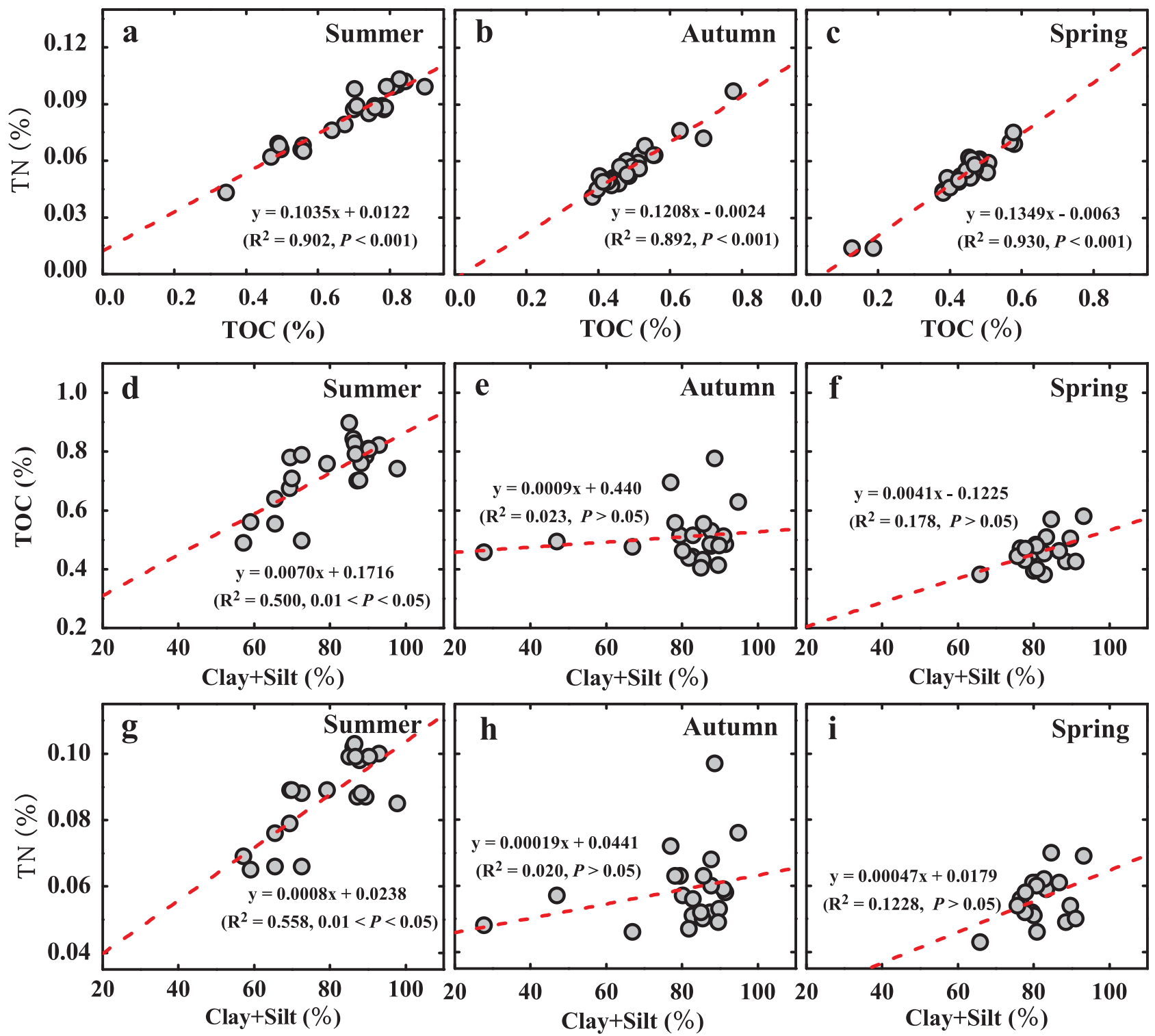

Fig. 3. Linear correlations between TOC and TN and fine-grained fraction of sediment (clay + silt).

sediments from high surface productivity areas could elevate the TOC/ TN ratios to be higher than typical algal values (Meyers, 1997). The relationships between TOC/TN ratios and $\delta^{13} \mathrm{C}$ can help determine whether TOC/TN ratios could be used to discriminate the sources of OM due to the stability of $\delta^{13} \mathrm{C}$ values in OM (Gearing et al., 1984; Ramaswamy et al., 2008; Gireeshkumar et al., 2013). As shown in Fig. 4a, b and c, by excluding only one data point, which was recorded at station S-1 in spring (13.69 for TOC/TN and $-24.42 \%$ for $\delta^{13} \mathrm{C}$ ), TOC/TN ratios against $\delta^{13} \mathrm{C}$ had no pronounced relationship in all the three seasons, indicating that the TOC/TN ratios were not suitable as source indicators. This could be attributed to the decomposition processes of OM (Wu et al., 2003).

\subsection{2. $\delta^{13} C$ and $\delta^{15} N$ values}

Stratigraphic fluctuations in $\delta^{13} \mathrm{C}$ and $\delta^{15} \mathrm{~N}$ values of SOM could reflect a combination of influence factors, including a shift in the relative contribution of autochthonous or allochthonous $\mathrm{OM}$, changing autochthonous primary productivity, and relative microbial biomass and activity (Torres et al., 2012). Marine OM typically has $\delta^{13} \mathrm{C}$ values ranging from $-19 \%$ to $-21 \%$ (Fry and Sherr, 1989). Terrestrial $C_{3}$ plants have an average $\delta^{13} \mathrm{C}$ value of $-27 \%$ o (-22\%o to $-33 \%$ ), while for the $\mathrm{C}_{4}$ plant, it is from $-9 \%$ to $-16 \%$ with a mean value of $-13 \%$ o (Pancost and Boot, 2004). Guo et al. (2006) reported that $C_{3}$ plant ecosystems dominate in North China, thus terrestrial $\mathrm{OM}$ is mainly derived from C3 vascular plants in the coastal waters of northern Shandong Peninsula. As shown in Table 4, the $\delta^{13} \mathrm{C}$ values of SOM ranged from $-22.56 \%$ to $-21.72 \%$ (mean $-22.10 \pm 0.21 \%$ ), $-23.84 \%$ to $-22.33 \%$ (mean $-23.05 \pm 0.43 \%$ ) and $-24.56 \%$ o to $-21.94 \%$ o (mean $-22.62 \pm 0.67 \%$ ) in summer, autumn and spring, respectively, indicative of a main algal $\mathrm{OM}$ source, especially in summer. Compared with other studies (Table 4), the $\delta^{13} \mathrm{C}$ values in this study were comparable to those of the Yellow Sea (Hu et al., 2013), the Bohai Bay (Hu et al., 2009) and the Sishili Bay (Liu et al., 2012), but lower than those of the coastal areas of the East China Sea and East China Sea shelf (Zhou et al., 2018).

As shown in Fig. 5d, e and $\mathrm{f}$, the trend of a seaward rise in $\delta^{13} \mathrm{C}$ values in spring reflects a relative increase in the contribution of marine-derived $\mathrm{OM}$ over the river-derived terrestrial fraction. Among them, two exceptionally depleted $\delta^{13} \mathrm{C}$ values were found at sites Y-1 (near Yangmadao Island) and S-1 (off Han River mouth), which could be ascribed to the anthropogenic influence. In autumn, the higher values were observed in the inshore places, which were contrary to those 

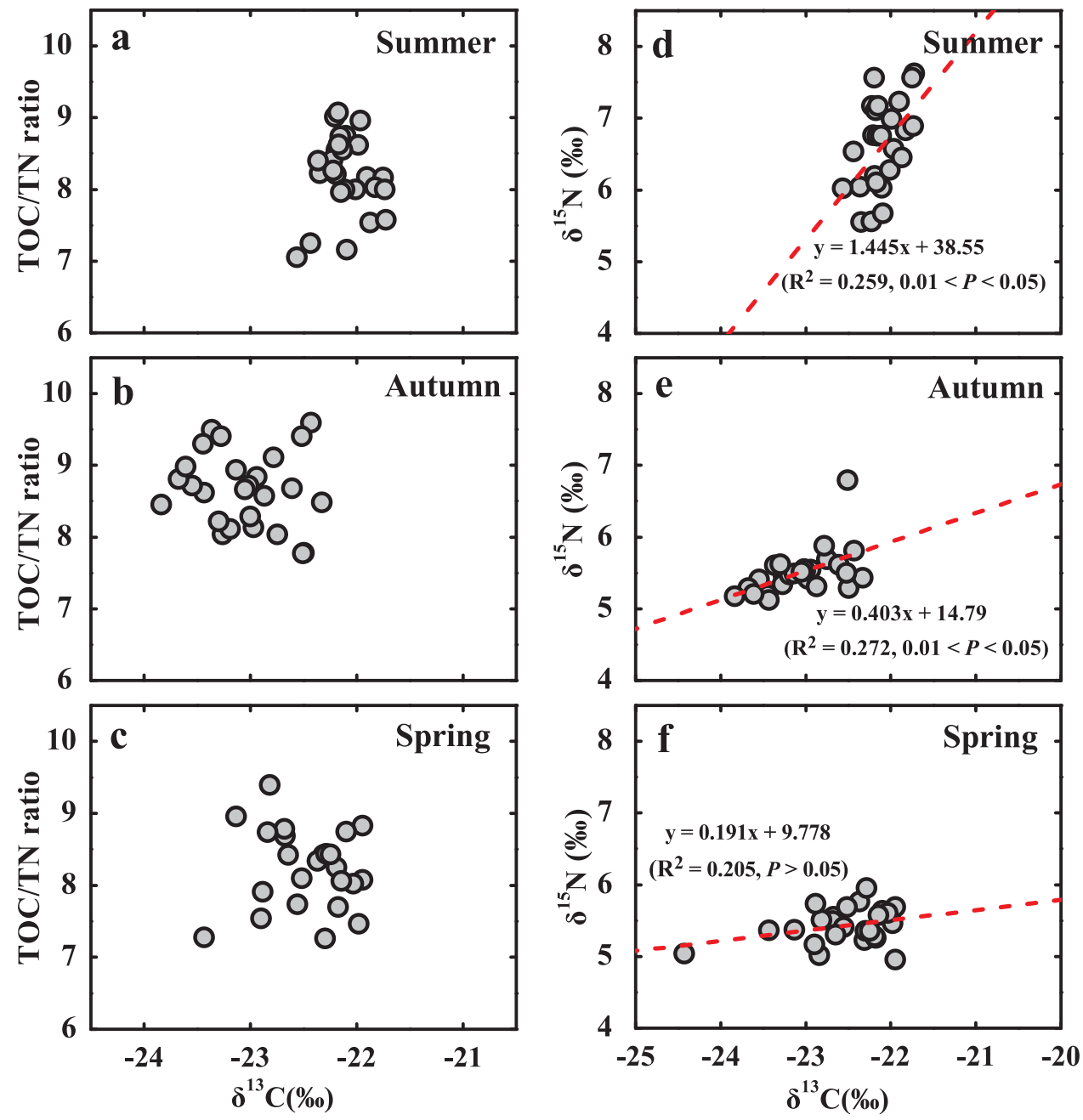

Fig. 4. Linear correlations between $\delta^{13} \mathrm{C}$ and TOC/TN ratios.

of spring. Meanwhile, the $\delta^{13} \mathrm{C}$ values at most stations in the western region were higher than those of the eastern region. Contrary to autumn, the $\delta^{13} \mathrm{C}$ values in summer were higher in the eastern region than those in the western region. These may be due to an integrated influence of biological activities, hydrodynamic conditions and human activities.

The data of $\delta^{15} \mathrm{~N}$ can also reflect the sources of sedimentary OM, as terrestrial and marine primary producers are different in their means of sequestering inorganic nitrogen. Marine primary producers mainly use nitrate, while terrestrial plants acquire both ammonium and nitrate from soil through root uptake. Generally, the $\delta^{15} \mathrm{~N}$ values of marine OM usually range from $3 \%$ to $12 \%$ o (mean $5-7 \%$ ) (Brandes and Devol, 2002; Lamb et al., 2006), while terrestrial OM vary from $-10 \%$ o to $10 \%$, with a mean of $2 \%$ (Gearing, 1988).

In this study, the $\delta^{15} \mathrm{~N}$ values ranged from $4.95 \%$ to $8.51 \% 0$ (Table 4), indicating the OM from marine organism had a more significant influence on its spatial distribution than from terrigenous input. In summer, the average value of $\delta^{15} \mathrm{~N}$ was $6.69 \pm 0.71 \%$ and significantly higher than in autumn (mean $5.51 \pm 0.33 \%$ ) and spring (mean $5.43 \pm 0.24 \%$ ). In comparison (Table 4), the $\delta^{15} \mathrm{~N}$ values in this study were higher than those of the East China Sea shelf (Zhou et al., 2018) but comparable to those of the Sishili Bay (Liu et al., 2012). Similar to the distribution of $\delta^{13} \mathrm{C}$, the $\delta^{15} \mathrm{~N}$ values in the places near to river mouths were lower than in the offshore waters in spring (Fig. 5i), and the $\delta^{15} \mathrm{~N}$ values at most stations in the eastern region were higher than those in the western region in summer (Fig. 5g). In autumn, the higher values were observed in the inshore places and relatively lower $\delta^{15} \mathrm{~N}$ values were found at two spots in a central east-west strip of the study area (Fig. 5h). During these three seasons, the lowest $\delta^{15} \mathrm{~N}$ value of $4.95 \%$ occurred at site Y-1 in spring reflecting a potential influence of terrigenous input from the Yangmadao Island.

On the whole, $\delta^{15} \mathrm{~N}$ values are affected more by biogeochemical processes than $\delta^{13} \mathrm{C}$ (Prahl et al., 1997). Wastewater can also change $\delta^{15} \mathrm{~N}$ values (Mckinney et al., 2001). Nitrate delivered from farm runoff and human sewage has elevated $\delta^{15} \mathrm{~N}$ values varying from $10 \%$ to $25 \%$ (Kendall, 1998). In Baltic rivers, Voss et al. (2006) estimated that farmland and wastewater effluents contribute $60-70 \%$ of nitrate. In Cape Cod, $\delta^{15} \mathrm{~N}$ values in the groundwater that is impacted by wastewater input are generally in a range of $6-8 \%$ (Cole et al., 2006). Liu et al. (2015) also reported that river input contribute significantly to sedimentary nitrogen in the Bohai Sea. In this study, a significant positive linear correlation between $\delta^{13} \mathrm{C}$ and $\delta^{15} \mathrm{~N}$ was found in summer $\left(\mathrm{R}^{2}=0.259,0.01<P<0.05\right.$; Fig. $\left.4 \mathrm{~d}\right)$ and autumn $\left(\mathrm{R}^{2}=0.272\right.$, $0.01<P<0.05$; Fig. 4e); while a weak positive correlation between them $\left(\mathrm{R}^{2}=0.205, P>0.05\right.$; Fig. $\left.4 \mathrm{f}\right)$ appeared in spring, indicating that other factors such as mineralization of organic matter or wastewater input might affect the $\delta^{15} \mathrm{~N}$ values. Therefore, only $\delta^{13} \mathrm{C}$ was used for the further exploration of the OM provenance in this study.

\subsubsection{Terrestrial versus autogenous contribution to organic carbon}

Since the $\delta^{13} \mathrm{C}$ of marine and terrestrial origins are different, the relative proportions of terrestrial organic carbon (Ter-OC) and marine autogenous organic carbon (AOC) present in sediments can be assessed with the $\delta^{13} \mathrm{C}$-based two end-member mixing model based on the work 

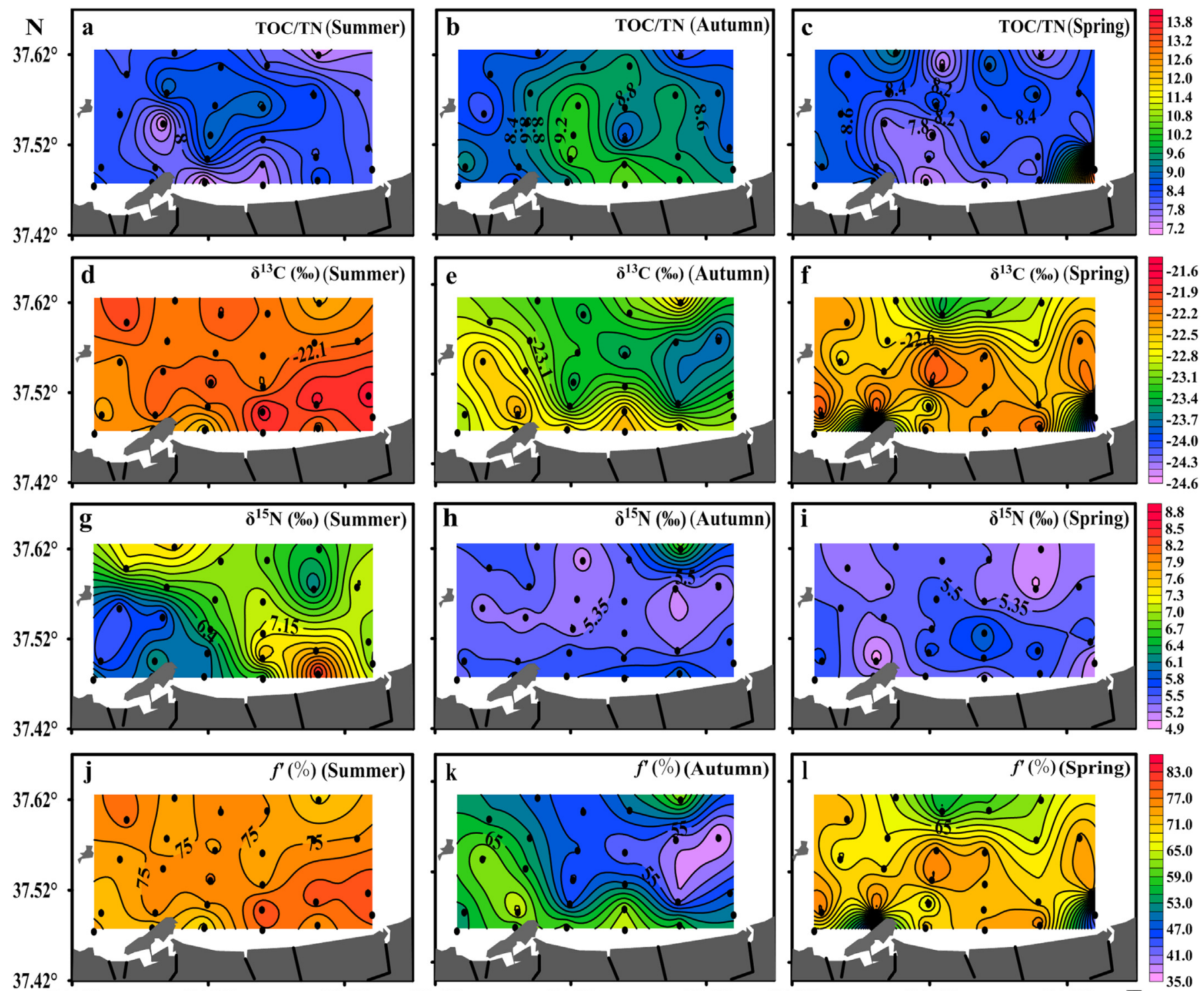

$121.50^{\circ}$

$121.70^{\circ}$

$121.90^{\circ}$

$121.50^{\circ}$

$121.70^{\circ}$

$121.90^{\circ}$

$121.50^{\circ}$

$121.70^{\circ}$

$121.90^{\circ}$

E

Fig. 5. Spatial distribution of $\delta^{13} \mathrm{C}, \delta^{15} \mathrm{~N}$, TOC/TN ratios and $f^{\prime}$.

of Calder and Parker (1968). The $\delta^{13} \mathrm{C}$ of $-20.5 \%$ was chosen as the marine end-member based on $\delta^{13} \mathrm{C}$ of phytoplankton in the north China Sea (Cai et al., 2000). Meanwhile, $-27 \%$ was chosen as the terrestrial end-member, which is close to that of the C3 plants, which are the dominant species of terrestrial vegetation in northern China (Guo et al., 2006). The calculation of terrestrial organic carbon contribution $(f)$ is gained based on the following equation:

$f(\%)=\left(\delta^{13} C_{\text {marine }}-\delta^{13} C_{\text {measured }}\right) /\left(\delta^{13} C_{\text {marine }}-\delta^{13} C_{\text {terrestrial }}\right) \times 100$

The contribution of AOC $\left(f^{\prime}\right)$ was obtained from:

$f^{\prime}(\%)=100-f$

The contents of AOC, expressed as the percentage of dry sediment weight, were obtained based on the following equation:

$A O C=T O C \times f^{\prime} \%$

The estimated results for the contribution of the terrestrial and autogenous organic carbon are summarized in Table 3. Taken as a whole, the surface sediments in this study area were dominated by marine derived organic carbon. In summer, the calculated $f^{\prime}$ ranged from $68.3 \%$ to $81.2 \%$ with a mean of $75.4 \pm 3.3 \%$. In autumn, the $f^{\prime}$ ranged from $48.7 \%$ to $71.9 \%$ with a mean of $60.8 \pm 6.6 \%$, and it varied from $37.5 \%$ to $77.8 \%$ with a mean of $67.4 \pm 10.3 \%$ in spring. Similar to $\delta^{13} \mathrm{C}$, in summer and spring (Fig. $5 \mathrm{j}$ and 1 ), the relatively lower $f^{\prime}$ values mainly appeared in the places close to river mouths, and the lowest value (37.56\%) occurred at site Y-1 near Yangmadao Island in spring, suggesting a possible impact of land-derived input. However, a generally seaward decreasing tendency of $f^{\prime}$ values appeared in autumn (Fig. 5k), which was different from that in summer and spring.

As for AOC, it can form locally or be transported from other coastal areas, however, part of AOC could be due to laterally transported. In this study, the values in summer were significantly higher than those in autumn and spring (Table 3). This could be explained by the growth of the marine primary producers in response to favorable temperature and the input of nutrients to this area transported from the land by the surrounding rivers. However, the high terrestrial organic carbon values appeared in autumn. The relative proportion of autogenic and terrestrial organic carbon in sediments is a integrated result of any natural and anthropogenic processes that influence the biogeochemical cycle of TOC such as waste discharge, hydrodynamic conditions, primary production in the overlying water body and early diagenesis (Duarte and Cebrian, 1996; Vizzini and Mazzola, 2006). Hence, it is essential to 
Table 5

Relationship between sediment carbon and nitrogen parameters and surface water environmental factors $(n=26)$.

\begin{tabular}{|c|c|c|c|c|c|c|c|c|c|c|}
\hline Season & & Temperature & Salinity & $\mathrm{NO}_{2}^{-}$ & $\mathrm{NO}_{3}^{-}$ & $\mathrm{NH}_{4}^{+}$ & DIN & $\mathrm{PO}_{4}^{3-}$ & $\mathrm{DSi}$ & DO \\
\hline \multirow[t]{4}{*}{ Summer } & $\delta^{13} \mathrm{C}$ & 0.143 & $0.405^{\mathrm{a}}$ & -0.004 & $0.576^{\mathrm{b}}$ & $-0.406^{\mathrm{a}}$ & $0.483^{\mathrm{a}}$ & 0.005 & -0.025 & -0.246 \\
\hline & $\delta^{15} \mathrm{~N}$ & 0.024 & 0.063 & -0.050 & 0.380 & -0.258 & 0.306 & 0.073 & 0.224 & $-0.401^{a}$ \\
\hline & $\mathrm{AOC}$ & 0.166 & 0.222 & -0.076 & 0.228 & -0.116 & 0.085 & -0.095 & 0.012 & -0.260 \\
\hline & Ter-OC & 0.035 & -0.086 & -0.059 & -0.287 & 0.210 & -0.259 & -0.130 & 0.068 & -0.055 \\
\hline \multirow[t]{4}{*}{ Autumn } & $\delta^{13} \mathrm{C}$ & -0.202 & 0.327 & -0.014 & 0.052 & -0.001 & 0.036 & -0.009 & 0.018 & 0.100 \\
\hline & $\delta^{15} \mathrm{~N}$ & 0.292 & 0.119 & 0.009 & 0.135 & -0.057 & 0.055 & 0.197 & -0.125 & -0.304 \\
\hline & $\mathrm{AOC}$ & -0.082 & -0.060 & 0.017 & 0.334 & 0.056 & 0.276 & 0.056 & 0.297 & 0.145 \\
\hline & Ter-OC & 0.178 & $-0.630^{c}$ & 0.059 & 0.276 & 0.072 & 0.248 & -0.007 & 0.247 & 0.062 \\
\hline \multirow[t]{4}{*}{ Spring } & $\delta^{13} \mathrm{C}$ & 0.180 & -0.259 & $-0.475^{\mathrm{a}}$ & 0.022 & 0.051 & 0.033 & -0.299 & 0.027 & -0.097 \\
\hline & $\delta^{15} \mathrm{~N}$ & 0.165 & $-0.397^{\mathrm{a}}$ & -0.240 & 0.251 & 0.376 & 0.366 & -0.306 & 0.179 & 0.332 \\
\hline & $\mathrm{AOC}$ & 0.228 & -0.201 & $-0.416^{\mathrm{a}}$ & -0.095 & 0.056 & -0.029 & $0.538^{\mathrm{b}}$ & -0.032 & -0.072 \\
\hline & Ter-OC & -0.185 & -0.004 & -0.180 & -0.247 & 0.067 & -0.104 & 0.164 & -0.091 & -0.126 \\
\hline
\end{tabular}

a $0.01<P<0.05$.

b $0.001<P<0.01$.

c $P<0.001$

understand the relationship between those factors and SOM.

\subsection{Relationship between SOM and environmental changes}

The accumulation of SOM is controlled by the supply, degradation and burial rates of OM. Various factors, such as temperature, DO and nutrients in water and sediment type, which vary seasonally and spatially, can affect the composition and content of SOM. Meanwhile, sediment biogeochemical processes are the main determinant of variations in physicochemical properties in overlying water, such as acidification and hypoxia. Thus, the Pearson's correlation and PCA were performed based on the water (temperature, salinity, DO and nutrients) and sedimentary $\left(\delta^{15} \mathrm{~N}, \delta^{13} \mathrm{C}\right.$, TOC, TN, and sediment grain size components) parameters to explain the interaction between environmental factors and biogeochemical variations of SOM (Tables 5-7, and Fig. 6).

Three principal components (PC1-PC3) were distinguished, which explains 55.3\% (summer), 61.4\% (autumn) and 76.1\% (spring) of the total variance, respectively. In summer (Fig. $6 \mathrm{a}$ and b), PC1 accounts for $24.1 \%$ of the total variance with high positive loadings for AOC, TOC, TN, $\delta^{13} \mathrm{C}, \delta^{15} \mathrm{~N}, \mathrm{NO}_{3}{ }^{-}(\mathrm{S})$, fine particle (clay and silt), $\mathrm{S}(\mathrm{B}), \mathrm{DSi}(\mathrm{B})$ and $\mathrm{NO}_{2}^{-}$(B), but negative loadings for sand and $\mathrm{T}$ (B). This component could help describe the marine autogenous OM in surface sediment and its relevant environmental factors. In summer, high primary productions led to an increased content of SOM, and reflected by the related data in Table 4, more AOC was accumulated in the fine fractions of sediments due to their relatively high surface area (Keil et al., 1994; Mayer, 1994). As shown in Table 5, the significant positive correlation between $\delta^{13} \mathrm{C}$ and $\mathrm{NO}_{3}{ }^{-}$with the Pearson's correlation coefficient $(r)$ of
$0.576(0.001<P<0.01)$ and slight positive correlation between AOC and $\mathrm{NO}_{3}{ }^{-}(r=0.228, P=0.183)$ indicate that $\mathrm{NO}_{3}{ }^{-}$in surface water may be a limiting factor in the growth of phytoplankton. Typically, fresh SOM could not be preserved for a long time, and most of them would decompose (Andrieux and Aminot, 1997; Rydin, 2000; Zhang et al., 2008) leading to the release of nutrients (Sinkko et al., 2013), and only about $10 \%$ AOC could be stored permanently in sediment (Nielsen et al., 2010). The significant positive correlation between AOC and bottom water DSi $(r=0.386,0.01<P<0.05$; Table 6$)$ and $\mathrm{NO}_{2}{ }^{-}(r=0.377,0.01<P<0.05$; Table 6$)$ in summer suggests that decomposition of marine autogenous OM may be an important supplement to the DSi and $\mathrm{NO}_{2}{ }^{-}$in deep water leading to the appearance of their high values (Table 2).

PC2 explains $17.4 \%$ of the total variance with high positive loadings for the variables of $\mathrm{T}(\mathrm{S}), \mathrm{T}(\mathrm{B})$ and $\mathrm{DO}(\mathrm{S})$, and high negative loadings for $\mathrm{DO}(\mathrm{B}), \mathrm{NO}_{2}^{-}(\mathrm{S}), \mathrm{DSi}(\mathrm{S})$ and $\mathrm{NO}_{3}^{-}$(B) (Fig. 6a). This component shows that the variations in water physicochemical parameters were associated with photosynthesis and decomposition of OM. Among them, the positive loadings for $\mathrm{T}(\mathrm{S})$ and $\mathrm{DO}(\mathrm{S})$ and negative loadings for $\mathrm{NO}_{2}^{-}(\mathrm{S}), \mathrm{DSi}(\mathrm{S})$ and $\mathrm{PO}_{4}{ }^{3-}(\mathrm{S})$ show that phytoplankton photosynthesis could lead to the increase of DO values and the decrease of $\mathrm{NO}_{2}{ }^{-}$, DSi and $\mathrm{PO}_{4}{ }^{3-}$ values in surface water. Meanwhile, the positive loadings for T (B) and $\mathrm{NH}_{4}{ }^{+}$(B), and the negative loadings for DO (B) and $\mathrm{NO}_{3}{ }^{-}$(B) suggest SOM can use the DO available in bottom water. With the decrease in DO concentration, nitrate ammonification may play a significant role in nitrogen cycling over nitrification, leading to the decrease of $\mathrm{NO}_{3}{ }^{-}$and increase of $\mathrm{NH}_{4}{ }^{+}$. Previous research shows that organisms in bottom water could stimulate nutrients release from sediment (Reddy et al., 1988) and $\mathrm{NH}_{4}{ }^{+}$is the main form of DIN under

Table 6

Relationship between sediment carbon and nitrogen parameters and bottom water environmental factors $(n=26)$.

\begin{tabular}{|c|c|c|c|c|c|c|c|c|c|c|}
\hline Season & & Temperature & Salinity & $\mathrm{NO}_{2}^{-}$ & $\mathrm{NO}_{3}{ }^{-}$ & $\mathrm{NH}_{4}^{+}$ & DIN & $\mathrm{PO}_{4}{ }^{3-}$ & $\mathrm{DSi}$ & DO \\
\hline \multirow[t]{4}{*}{ Summer } & $\delta^{13} \mathrm{C}$ & -0.261 & 0.333 & $0.532^{\mathrm{a}}$ & -0.098 & -0.057 & -0.076 & 0.164 & 0.358 & -0.069 \\
\hline & $\delta^{15} \mathrm{~N}$ & $-0.635^{\mathrm{b}}$ & $0.631^{b}$ & $0.451^{\mathrm{c}}$ & -0.047 & -0.352 & -0.299 & -0.127 & 0.307 & 0.179 \\
\hline & $\mathrm{AOC}$ & -0.266 & 0.222 & $0.377^{\mathrm{c}}$ & $-0.418^{c}$ & -0.007 & -0.255 & 0.211 & $0.386^{c}$ & -0.114 \\
\hline & Ter-OC & 0.005 & -0.002 & -0.171 & -0.320 & 0.021 & -0.198 & 0.013 & 0.133 & -0.089 \\
\hline \multirow[t]{4}{*}{ Autumn } & $\delta^{13} \mathrm{C}$ & -0.190 & -0.176 & 0.078 & 0.281 & -0.041 & 0.186 & -0.260 & 0.202 & 0.194 \\
\hline & $\delta^{15} \mathrm{~N}$ & 0.300 & -0.310 & 0.161 & -0.062 & -0.091 & -0.092 & 0.099 & -0.131 & -0.284 \\
\hline & AOC & -0.074 & -0.350 & -0.045 & 0.155 & -0.124 & 0.047 & -0.156 & 0.270 & 0.043 \\
\hline & Ter-OC & 0.170 & -0.192 & -0.146 & -0.237 & -0.084 & -0.224 & 0.164 & 0.083 & -0.215 \\
\hline \multirow[t]{4}{*}{ Spring } & $\delta^{13} \mathrm{C}$ & -0.146 & 0.005 & -0.293 & 0.141 & 0.049 & 0.068 & 0.170 & 0.176 & 0.010 \\
\hline & $\delta^{15} \mathrm{~N}$ & 0.145 & 0.052 & -0.152 & 0.137 & -0.119 & -0.129 & 0.228 & 0.085 & 0.206 \\
\hline & AOC & -0.092 & 0.072 & -0.288 & 0.038 & 0.097 & 0.050 & $0.625^{\mathrm{c}}$ & 0.094 & 0.029 \\
\hline & Ter-OC & -0.196 & $0.415^{\mathrm{c}}$ & -0.386 & -0.196 & -0.114 & -0.142 & $0.405^{c}$ & 0.046 & -0.148 \\
\hline
\end{tabular}

\footnotetext{
a $0.001<P<0.01$.

b $0.001<P<0.001$.

c $P<0.001$.
} 
Table 7

Relationship among sediment carbon and nitrogen parameters and related environmental factors $(n=26)$.

\begin{tabular}{|c|c|c|c|c|c|c|c|c|c|}
\hline Season & & Clay & Silt & Sand & $\mathrm{TN}$ & TOC/TN & TOC & $\delta^{13} \mathrm{C}$ & $\delta^{15} \mathrm{~N}$ \\
\hline \multirow[t]{4}{*}{ Summer } & $\delta^{13} \mathrm{C}$ & 0.238 & 0.230 & -0.251 & 0.265 & 0.041 & 0.242 & 1.000 & \\
\hline & $\delta^{15} \mathrm{~N}$ & 0.236 & 0.299 & -0.304 & 0.272 & 0.143 & 0.292 & $0.413^{\mathrm{a}}$ & 1.000 \\
\hline & AOC & $0.476^{\mathrm{a}}$ & $0.422^{\mathrm{a}}$ & $-0.474^{\mathrm{a}}$ & $0.949^{b}$ & $0.497^{c}$ & $0.986^{\mathrm{b}}$ & $0.393^{\mathrm{a}}$ & 0.342 \\
\hline & Ter-OC & 0.303 & 0.255 & -0.292 & $0.731^{\mathrm{b}}$ & $0.542^{c}$ & $0.813^{\mathrm{b}}$ & -0.353 & 0.058 \\
\hline \multirow[t]{4}{*}{ Autumn } & $\delta^{13} \mathrm{C}$ & $-0.502^{\mathrm{b}}$ & -0.058 & 0.198 & 0.254 & -0.136 & 0.230 & 1.000 & \\
\hline & $\delta^{15} \mathrm{~N}$ & -0.373 & 0.012 & 0.103 & 0.165 & -0.196 & 0.120 & $0.522^{c}$ & 1.000 \\
\hline & $\mathrm{AOC}$ & $-0.451^{\mathrm{a}}$ & 0.186 & -0.011 & $0.865^{\mathrm{b}}$ & -0.121 & $0.902^{\mathrm{b}}$ & $0.620^{\mathrm{b}}$ & 0.316 \\
\hline & Ter-OC & 0.164 & 0.281 & -0.272 & $0.589^{c}$ & 0.026 & $0.649^{\mathrm{b}}$ & $-0.579^{c}$ & -0.286 \\
\hline \multirow[t]{4}{*}{ Spring } & $\delta^{13} \mathrm{C}$ & $0.406^{\mathrm{a}}$ & $0.630^{\mathrm{b}}$ & $-0.609^{c}$ & $0.755^{\mathrm{b}}$ & $-0.568^{c}$ & $0.756^{\mathrm{b}}$ & 1.000 & \\
\hline & $\delta^{15} \mathrm{~N}$ & 0.142 & 0.273 & -0.255 & 0.106 & -0.226 & 0.122 & 0.286 & 1.000 \\
\hline & $\mathrm{AOC}$ & $0.443^{\mathrm{a}}$ & $0.695^{\mathrm{b}}$ & $-0.671^{b}$ & $0.923^{\mathrm{b}}$ & $-0.557^{c}$ & $0.952^{\mathrm{b}}$ & $0.897^{\mathrm{b}}$ & 0.168 \\
\hline & Ter-OC & 0.246 & 0.289 & -0.295 & $0.465^{\mathrm{a}}$ & -0.167 & $0.496^{c}$ & -0.119 & -0.080 \\
\hline
\end{tabular}

\footnotetext{
a $0.01<P<0.05$.

b $0.001<P<0.001$.

c $0.001<P<0.01$.
}

anaerobic conditions (Ye et al., 2006; Qiu et al., 2011). Besides, a slight negative correlation between DO in bottom water and AOC $(r=-0.114$, $P=0.558$; Table 6 ) indicates that the concentration of DO in bottom water can influence the preservation of AOC to some extent. It also provides a clue that the decomposition of AOC could promote the formation of hypoxia in bottom water in summer. Some studies show anoxia as the principal factor in controlling the preservation of SOM (Paropkari et al., 1992, 1993; Van der Weijden et al., 1999). That is because low oxygen levels could prevent redox reaction of the deposited OM to some extent and reduce the effects of bottom-dwelling organisms that most likely depend on oxygen for respiration from scavenging the deposited OM as food (Bralower and Thierstein, 1984). However, it is also believed that primary productivity in overlying water is also a key factor in the preservation of OM (Pedersen and Calvert, 1991). In this study, the positive correlation between AOC and $\mathrm{NO}_{3}{ }^{-}$in surface water (Table 5) and the negative correlation between AOC and DO in bottom water (Table 6) indicate the primary productivity and the DO dynamics could together control the preservation of AOC in summer.

For PC3 (13.8\% of the total variance), high positive loadings for $\mathrm{NO}_{3}{ }^{-}(\mathrm{S})$, DIN (S) and $\mathrm{S}(\mathrm{S})$, and negative loadings for Ter-OC were identified. This component could be interpreted as the terrestrial OM and its relevant environmental factors. Terrestrial OM, which is delivered mainly by river inflow, includes organic detritus of terrestrial origin, those produced in situ by freshwater phytoplankton in rivers, atmospheric fallout and human discharges (Maksymowska et al., 2000). The significant positive correlation between Ter-OC and TN $(r=0.731$, $P<0.001$; Table 7) and TOC $(r=0.813, P<0.001$; Table 7) suggest terrestrial $\mathrm{OC}$ is an important component of TOC in summer. However, no significant correlation between Ter-OC and water parameters was found, indicating that the decomposition of terrestrial OM has less influence on the water environment. This is because terrestrial $\mathrm{OM}$ is more resistant to further degradation in marine environment (Boer et al., 2009) and thus the decomposition of marine autogenous OM is dominant in summer.

In autumn (Fig. $6 \mathrm{c}$ and d), PC1 explains $26.5 \%$ of the total variance, with high positive loadings for DO (S), DO (B), DSi (B), S (B), DIN (B), $\mathrm{NH}_{4}{ }^{+}$(B) and sand, and negative loadings for $\mathrm{T}(\mathrm{B}), \mathrm{T}(\mathrm{S}), \mathrm{PO}_{4}{ }^{3-}$ (S), $\mathrm{PO}_{4}{ }^{3-}$ (B) and silt. Like PC2 in summer, this component reflects the variation in water physicochemical parameters associated with photosynthesis and decomposition of OM. In surface water, the photosynthesis is of phytoplankton could reduce the $\mathrm{PO}_{4}{ }^{3-}$ values. On the contrary, in bottom water, the decomposition of OM could release DSi and DIN $\left(\mathrm{NH}_{4}{ }^{+}, \mathrm{NO}_{3}{ }^{-}\right.$and $\left.\mathrm{NO}_{2}{ }^{-}\right)$, which is similar to that in summer. However, low primary productivity and high decomposition rate of OM occurred in autumn, resulting in the less preservation of $\mathrm{OM}$ in surface sediment (Table 4). The DO in bottom water had no negative correlation with
AOC, but it showed a slight negative correlation with Ter-OC ( $r=$ $0.215, P=0.312$; Table 6 ), suggesting that DO is not a key factor in controlling the preservation of marine autogenous OM while it has a potential influence on the preservation of terrestrial OM, which is different from that in summer. Generally, SOM decomposition is mediated by a variety of aerobic and anaerobic microbial processes, which could progressively modify the OM composition because different fractions of OM degrade at different rates. Compared with terrestrial OM, marine autogenous OM is more easily decomposed. When DO is insufficient, terrestrial OM decomposition could be limited. So, terrestrial OM is less decomposed in summer. When DO is relatively sufficient, the decomposition of terrestrial $\mathrm{OM}$ and marine autogenous OM could be different. As shown in the autumn results (Table 6), the decomposition of marine autogenous OM was not subject to the DO effect with no negative correlation between DO and AOC; in contrast, the Ter-OC seemed to be affected by the concentration of DO, that is, the higher the DO values are, the more obviously the Ter-OC decomposes. With the decomposition of OM, some nutrients can be released from surface sediment to bottom water (Schultz and Urban, 2008). However, although the low TOC values appeared in autumn (Table 4), the nutrients in bottom water did not increase but was lower than in summer (Table 2), which are different from previous studies (Wen et al., 2009; Zhao et al., 2012). This may be explained from two aspects. On one hand, the decomposition of OM in autumn could be relatively weak due to the low temperature and OM values in surface sediment. On the other hand, this study area is affected by ocean circulation obviously in late autumn (Li et al., 2016), and nutrients in bottom water could be diluted by external water.

PC2, which accounts for $18.7 \%$ of the total variance, has high positive loadings for the combined variables $\mathrm{NO}_{2}^{-}$(S), DSi (S), DIN (S), $\mathrm{NO}_{3}{ }^{-}(\mathrm{S}), \mathrm{NH}_{4}{ }^{+}(\mathrm{S}), \mathrm{TN}$ and AOC, reflecting the importance of those nutrients in the accumulation of AOC, which was somewhat different from that of the PC1 in summer. The slight positive correlation between AOC and DSi $\left(r=0.297, P=0.149\right.$; Table 5) and $\mathrm{NO}_{3}{ }^{-}(r=0.334$, $P=0.101$; Table 5 ) in surface water suggests that primary productivity may be a possible factor in the preservation of AOC. PC2 has negative loadings for $\mathrm{NO}_{2}^{-}$(B) and $\mathrm{NH}_{4}{ }^{+}$(B) suggesting that the additional $\mathrm{NO}_{2}^{-}$ and $\mathrm{NH}_{4}{ }^{+}$in bottom water had a common source, which could be derived from the decomposition of OM.

PC3 explains $16.2 \%$ of the total variance and has high positive loadings for the combined variables of AOC, TOC, TN, $\delta^{13} \mathrm{C}$ and sand, and negative loading of clay and S (B). This component shows that AOC content was low in fine-grained sediment, which was different from that of PC1 in summer. A significant negative correlation between AOC and clay $(r=-0.451,0.01<P<0.05$; Table 7) was found in autumn indicating that fine-grained sediment is not conducive to the preservation of marine autogenous $\mathrm{OM}$, which is unusual and contradicts 

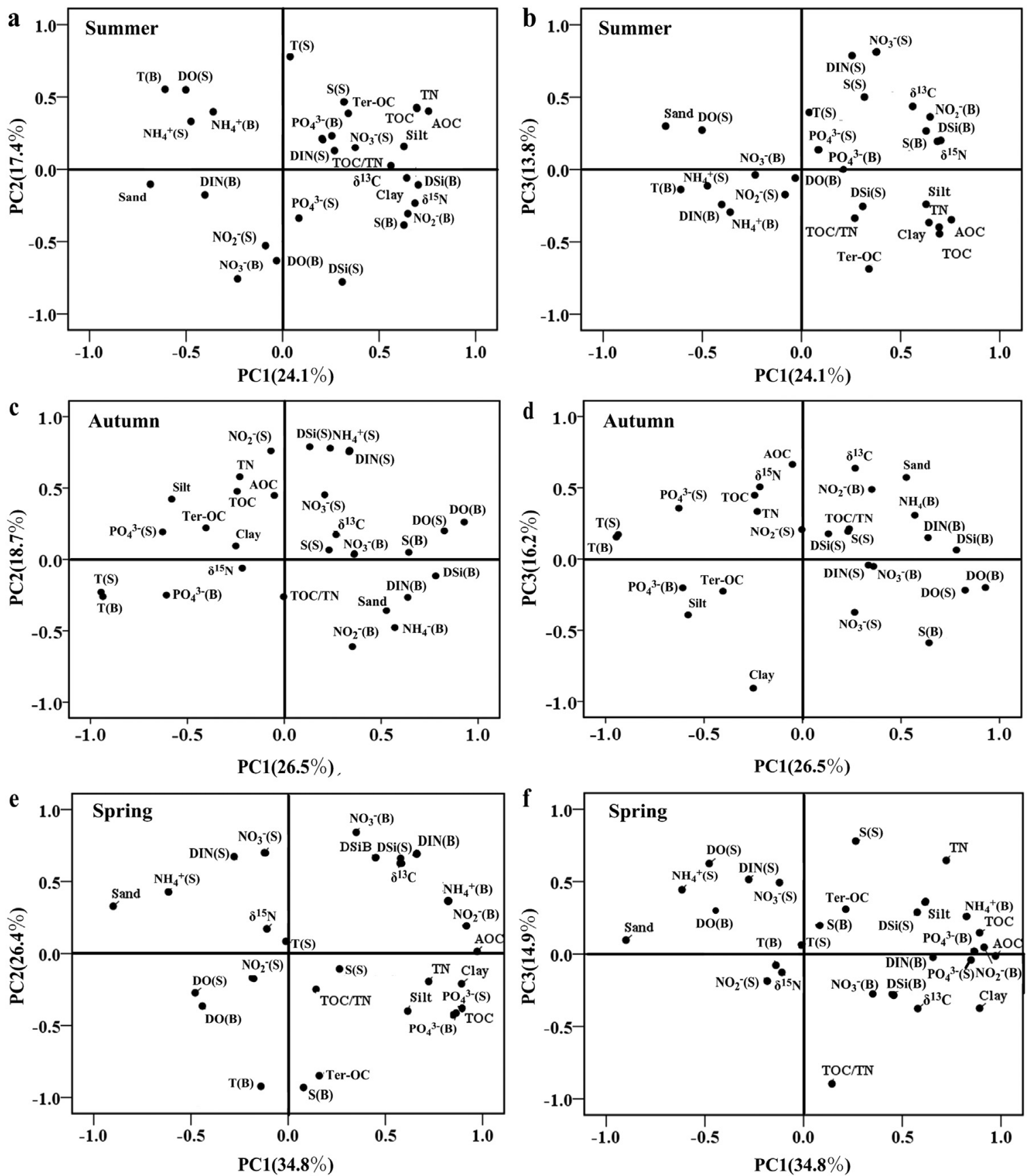

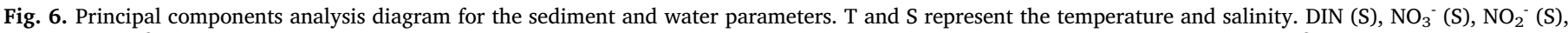

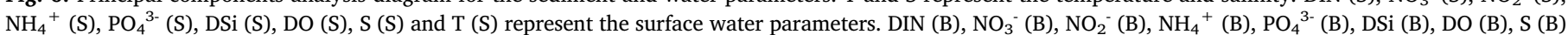
and $\mathrm{T}(\mathrm{B})$ represent the bottom water parameters.

the finding in Keil et al. (1994), and is hard to be well explained. A possible explanation is that the hydrodynamic conditions are strong in autumn; the fine particles in sediments are easily resuspended, which is beneficial to the decomposition of autogenous marine OM in finegrained sediment.

In spring (Fig. 6e and f), PC1 explains $34.8 \%$ of the total variance, and shows high positive loadings for AOC, TOC, TN, $\delta^{13} \mathrm{C}, \delta^{15} \mathrm{~N}$, clay and silt, $\mathrm{PO}_{4}{ }^{3-}(\mathrm{S}), \mathrm{DSi}(\mathrm{S}), \mathrm{NH}_{4}{ }^{+}$(B), $\mathrm{NO}_{2}{ }^{-}$(B), DIN (B), $\mathrm{PO}_{4}{ }^{3-}$ (B) and $\mathrm{S}$ (B). The variables with negative PC1 loadings include sand, DO (S), DO (B), and $\mathrm{NH}_{4}{ }^{+}(\mathrm{S})$. This component could help describe marine autochthonous $\mathrm{OM}$ in surface sediments and relevant environmental factors. Consistent with summer, more AOC was accumulated in fine-grained sediment (Keil et al., 1994; Zhou et al., 2016). The significant positive correlation between $\mathrm{AOC}$ and surface water $\mathrm{PO}_{4}{ }^{3-}(r=0.538$,
$0.001<P<0.01$; Table 5) indicates that primary productivity could control the preservation of $\mathrm{AOC}$ and $\mathrm{PO}_{4}{ }^{3-}$ could be a key factor in the growth of phytoplankton, which was different from that in summer and autumn. Like in autumn, DO in bottom water had no negative correlation with AOC, but it had a slight negative correlation with terrestrial OC $(r=-0.148, P=0.470$; Table 6$)$.

PC2 accounts for $26.4 \%$ of the total variance. $\delta^{13} \mathrm{C}, \mathrm{NO}_{3}{ }^{-}(\mathrm{S}), \mathrm{NO}_{3}{ }^{-}$ (B), DIN (S), DIN (B), DSi (S) and DSi (B) are characterized by high positive loadings. Negative loadings are evident for Ter-OC, $S$ (B) and T (B). This component could help describe terrestrial OM and the source of nutrients. It seems that water $\mathrm{NO}_{3}{ }^{-}$and DSi had a common source, which could come from the terrestrial input. In bottom water, a significant positive correlation between Ter-OC and $\mathrm{PO}_{4}{ }^{3-}(r=0.405$, $0.01<P<0.05$; Table 6) were found indicating that some of the 
bottom water $\mathrm{PO}_{4}{ }^{3-}$ could be derived from the terrestrial input. A weak negative correlation between Ter-OC and bottom water DO $(r=-0.148$, $P=0.470$; Table 6 ) indicated the bottom water DO levels could influence the preservation of terrestrial OM to some extent.

PC3, which explains $14.9 \%$ of the total variance, has high positive loadings for the combined variables of $\mathrm{NO}_{3}{ }^{-}(\mathrm{S})$, DIN (S), $\mathrm{NH}_{4}{ }^{+}$(S), DO (S) and TN, and negative loading for TOC/TN. This component could explain that $\mathrm{NO}_{3}{ }^{-}(\mathrm{S})$, DIN (S) and $\mathrm{NH}_{4}{ }^{+}(\mathrm{S})$ in the surface water played an important role in the accumulation of TN. The OM synthesized by marine primary producers was the main source of TN in surface sediment, and $\mathrm{NO}_{3}{ }^{-}$and $\mathrm{NH}_{4}{ }^{+}$in surface water were raw materials for photosynthesis in spring.

\section{Conclusions}

This study gives insights into the sources and fate of SOM and their controlling factors in the coastal waters of northern Shandong Peninsula. In summer, the amounts of TOC and TN were significantly higher than that in autumn and spring due to the fact that high OM supply was derived from high primary production. The relatively high abundance of SOM was found in the offshore places in summer and spring, which was contrary to autumn. TOC had a good relationship with TN during this investigation, suggesting that they were homologous. However, the intercept of their linear regression equation was $>0$ in summer, indicating that a considerable fraction of TN was inorganic. The values of $\delta^{15} \mathrm{~N}, \delta^{13} \mathrm{C}$ and TOC/TN ratios indicated a mixed contribution of marine and terrestrial origins to SOM. Marine autochthonous organic carbon was estimated to be account for $75.4 \pm 3.3 \%, 60.8 \pm 6.6 \%$ and $67.4 \pm 10.3 \%$ of the TOC contents in summer, autumn and spring, respectively.

Pearson's correlation and PCA were performed based on the data of water and sediment parameters to explain the interaction between environmental factors and biogeochemical features of SOM. The results show that DO dynamics and primary productivity were important factors in controlling the preservation of SOM. In summer, the high primary productivity in surface water and the low DO values in bottom water could together control the preservation of SOM, and nitrate in surface water had the most obvious effects on autogenous organic carbon (AOC) and may be a principal factor in promoting the growth of phytoplankton. Different from those in summer, the SOM values were relatively low in autumn and spring, due to the high decomposition rate and high oxygen level in bottom water. The decomposition of marine autochthonous OM was dominant in summer, which could be a main contributor to hypoxia in bottom water. In contrast, some of terrestrial OM could be decomposed in autumn and spring, and DO dynamics in bottom water could influence the preservation of terrestrial OM to some extent. In summer and spring, SOM was more enriched in fine-grained sediment. However, AOC was significantly negatively correlated with clay sediment fraction in autumn, which is hard to be well explained based on the evidence gained in this research. With the decomposed OM, some nutrients could be released from surface sediment, which seemed to be a key determinant of high $\mathrm{DSi}, \mathrm{NO}_{2}{ }^{-}$and $\mathrm{NH}_{4}{ }^{+}$values in bottom water in summer.

\section{Acknowledgments}

This work was financially supported by the Aoshan Technology Innovation Program of the Qingdao National Laboratory for Marine Science and Technology (2016ASKJ02-4), the Joint Fund of National Natural Science Foundation of China and Shandong Province (U1606404) and the Strategic Priority Research Program of the Chinese Academy of Sciences (XDA11020702). The assistance of Kai Liu in the sample collection is greatly appreciated.

\section{References}

Alexander, C.R., Demaster, D.J., Nittrouer, C.A., 1991. Sediment accumulation in a modern epicontinental-shelf setting: the Yellow Sea. Mar. Geol. 98 (1), 51-72.

Andrews, J., Greenaway, A., Dennis, P., 1998. Combined carbon isotope and C/N ratios as indicators of source and fate or organic matter in a poorly-flushed tropical estuary, Hunts Bay, Kingston, Jamaica. Estuar. Coast. Shelf Sci. 46 (5), 743-756.

Andrieux, F., Aminot, A., 1997. A two-year survey of phosphorus speciation in the sediments of the Bay of Seine (France). Cont. Shelf Res. 17 (10), 1229-1245.

Aydin-Onen, S., Kocak, F., Kucuksezgin, F., 2012. Evaluation of spatial and temporal variations of inorganic nutrient species in the Eastern Aegean Sea waters. Mar. Pollut. Bull. 64 (12), 2849-2856.

Bi, N., Yang, Z., Wang, H., Fan, D., Sun, X., Lei, K., 2011. Seasonal variation of suspendedsediment transport through the southern Bohai strait estuarine. Estuar. Coast. Shelf Sci. 93 (3), 239-247.

Boer, P.D., Postma, G., Zwan, K.V.D., Burgess, P., Kukla, P., 2009. Modelling Source-Rock Distribution and Quality Variations: The Organic Facies Modelling Approach.

Analogue and Numerical Modelling of Sedimentary Systems: From Understanding to Prediction. Wiley-Blackwell, pp. 239-274.

Bralower, T.J., Thierstein, H.R., 1984. Low productivity and slow deep-water circulation in mid-Cretaceous oceans. Geology 12 (10), 614-618.

Brandes, J.A., Devol, A.H., 2002. A global marine-fixed nitrogen isotopic budget: implications for holocene nitrogen cycling. Glob. Biogeochem. Cycles 16 (4), 1-14.

Cai, D., Hong, X., Mao, X., Zhang, S., Gao, S., 2000. A preliminary study on benthos food web structure of tidal zone in the Laoshan Bay by using stable carbon isotopes. Acta Oceanol. Sin. 19 (4), 81-89.

Calder, J.A., Parker, P.L., 1968. Stable carbon isotope ratios as indexes of petrochemical pollution of aquatic systems. Environ. Sci. Technol. 2 (7), 535-539.

Chen, C.T.A., Lin, C.M., Huang, B.T., Chang, L.F., 1996. Stoichiometry of carbon, hydrogen, nitrogen, sulfur and oxygen in the particulate matter of the western North Pacific marginal seas. Mar. Chem. 54 (1-2), 179-190.

Chen, H., Li, J., Xing, X., Du, Z., Chen, G., 2015. Unexpected diversity of magnetococci in intertidal sediments of Xiaoshi Island in the North Yellow Sea. J. Nanomater (Article ID 902121).

Cole, M.L., Kroeger, K.D., Mcclelland, J.W., Valiela, I., 2006. Effects of watershed land use on nitrogen concentrations and $\delta^{15}$ nitrogen in groundwater. Biogeochemistry 77 (2), 199-215.

Dai, J., Song, J., Li, X., Yuan, H., Li, N., Zheng, G., 2007. Environmental changes reflected by sedimentary geochemistry in recent hundred years of Jiaozhou Bay, North China. Environ. Pollut. 145 (3), 656-667.

Duarte, C.M., Cebrian, J., 1996. The fate of marine autotrophic production. Limnol. Oceanogr. 41 (8), 1758-1766.

Emerson, S., Hedges, J.I., 1988. Processes controlling the organic carbon content of open ocean sediments. Paleoceanography 3 (5), 621-634.

Fry, B., Sherr, E.B., 1989. $\delta^{13} \mathrm{C}$ measurements as indicators of carbon flow in marine and freshwater ecosystems. In: Rundel, P.W., Ehleringer, J.R., Nagy, K.A. (Eds.), Stable Isotopes in Ecological Research. Ecological Studies (Analysis and Synthesis). 68. Springer, New York, pp. 196-229.

Gao, X.L., Yang, Y.W., Wang, C.Y., 2012. Geochemistry of organic carbon and nitrogen in surface sediments of coastal Bohai Bay inferred from their ratios and stable isotopic signatures. Mar. Pollut. Bull. 64 (6), 1148-1155.

Gearing, J.N., 1988. The Use of Stable Isotope Ratios for Tracing the Nearshore-Offshore Exchange of Organic Matter Coastal-offshore Ecosystem Interactions. Springer, Berlin Heidelberg, pp. 69-101.

Gearing, J.N., Gearing, R.J., Rudrick, D.T., Requejo, A.G., Hutchins, M.J., 1984. Isotope variation of organic carbon in a phytoplankton-based temperate estuary. Geochim. Cosmochim. Acta 48 (5), 1089-1098.

Gireeshkumar, T.R., Deepulal, P.M., Chandramohanakumar, N., 2013. Distribution and sources of sedimentary organic matter in a tropical estuary, south west coast of India (Cochin estuary): a baseline study. Mar. Pollut. Bull. 66 (1-2), 239-245.

Goñi, M.A., Ruttenberg Amp, K.C., Eglinton, T.I., 1997. Sources and contribution of terrigenous organic carbon to surface sediments in the Gulf of Mexico. Nature 389 (6648), 275-278.

Goñi, M.A., Teixeira, M.J., Perkey, D.W., 2003. Sources and distribution of organic matter in a river-dominated estuary (Winyah Bay, SC, USA). Estuar. Coast. Shelf Sci. 57 (5), 1023-1048.

Gordon, E.S., Goñi, M.A., 2003. Sources and distribution of terrigenous organic matter delivered by the Atchafalaya River to sediments in the northern Gulf of Mexico. Geochim. Cosmochim. Acta 67 (13), 2359-2375.

Guo, Z., Li, J., Feng, J., Ming, F., Yang, Z., 2006. Compound-specific carbon isotope compositions of individual long-chain $n$-alkanes in severe Asian dust episodes in the North China coast in 2002. Chin. Sci. Bull. 51 (17), 2133-2140.

Han, Q.Y., Liu, D.Y., 2014. Temporal and spatial variations in the distribution of mac roalgal communities along the Yantai Coast, China. Chin. J. Oceanol. Limn. 32 (3), 595-607.

Hu, J., Peng, P., Jia, G., Mai, B., Zhang, G., 2006. Distribution and sources of organic carbon, nitrogen and their isotopes in sediments of the subtropical Pearl River Estuary and adjacent shelf, Southern China. Mar. Chem. 98 (2), 274-285.

Hu, L., Guo, Z., Feng, J., Yang, Z., Fang, M., 2009. Distributions and sources of bulk organic matter and aliphatic hydrocarbons in surface sediments of the Bohai Sea, China. Mar. Chem. 113 (3), 197-211.

Hu, L., Shi, X., Guo, Z., Wang, H., Yang, Z., 2013. Sources, dispersal and preservation of sedimentary organic matter in the Yellow Sea: the importance of depositional hydrodynamic forcing. Mar. Geol. 335 (1), 52-63.

Huon, S., Grousset, F.E., Burdloff, D., Bardoux, G., Mariotti, A., 2002. Sources of fine- 
sized organic matter in North Atlantic Heinrich Layers: $\delta^{13} \mathrm{C}$ and $\delta^{15} \mathrm{~N}$ tracers. Geochim. Cosmochim. Acta 66 (2), 223-239.

Kao, S.J., Liu, K.K., 2000. Stable carbon and nitrogen isotope systematics in a humandisturbed watershed (Lanyang-Hsi) in Taiwan and the estimation of biogenic particulate organic carbon and nitrogen fluxes. Glob. Biogeochem. Cycles 14 (1), 189-198.

Keil, R.G., Tsamakis, E., Fuh, C.B., Giddings, J.C., Hedges, J.I., 1994. Mineralogical and textural controls on the organic composition of coastal marine sediments: hydrodynamic separation using SPLITT-fractionation. Geochim. Cosmochim. Acta 58 (2), 879-893.

Keil, R.G., Tsamakis, E., Giddings, J.C., Hedges, J.I., 1998. Biochemical distributions (amino acids, neutral sugars, and lignin phenols) among size-classes of modern marine sediments from the Washington coast. Geochim. Cosmochim. Acta 62 (8), 1347-1364.

Kendall, C., 1998. Tracing nitrogen sources and cycling in catchments. In: Kendall, C., McDonnell, J.J. (Eds.), Isotope Tracers in Catchment Hydrology. Elsevier, Amsterdam, pp. 519-576.

Kristensen, E., Bouillon, S., Dittmar, T., Marchand, C., 2008. Organic carbon dynamics in mangrove ecosystems: a review. Aquat. Bot. 89 (2), 201-219.

Kuwae, M., Yamaguchi, H., Tsugeki, N.K., Miyasaka, H., Fukumori, K., Ikehara, M., Genkai-Kato, M., Omori, K., Sugimoto, T., Ishida, S., Takeoka, H., 2007. Spatial distribution of organic and sulfur geochemical parameters of oxic to anoxic surface sediments in Beppu Bay in southwest Japan. Estuar. Coast. Shelf Sci. 72 (1-2), 348-358.

Lamb, A.L., Wilson, G.P., Leng, M.J., 2006. A review of coastal palaeoclimate and relative sea-level reconstructions using $\delta^{13} \mathrm{C}$ and $\mathrm{C} / \mathrm{N}$ ratios in organic material. Earth-Sci. Rev. 75 (1), 29-57.

Li, G.X., Qiao, L.L., Dong, P., Ma, Y.Y., Xu, J.S., Liu, S.D., Liu, Y., Li, J.C., Li, P., Ding, D., Wang, N., Olusegun, A.D.D., Liu, L., 2016. Hydrodynamic condition and suspended sediment diffusion in the Yellow Sea and East China Sea. J. Geophys. Res. 121 (8), 6204-6222.

Liu, D., Li, X., Emeis, K.C., Wang, Y., Richard, P., 2015. Distribution and sources of organic matter in surface sediments of Bohai Sea near the Yellow River Estuary, China. Estuar. Coast. Shelf Sci. 165 (5), 128-136.

Liu, D.Y., Shen, X.H., Wang, Y.J., Chen, Y.J., Li, L., 2012. Tracking the sources of organic matter in the surface sediments of Sishili Bay, Northern Yellow Sea and the environmental implication. Acta Oceanol. Sin. 34 (5), 205-212.

Liu, M., Hou, L.J., Xu, S.Y., Ou, D.N., Yang, Y., Yu, J., 2006. Organic carbon and nitrogen stable isotopes in the intertidal sediments from the Yangtze Estuary, China. Mar Pollut. Bull. 52 (12), 1625-1633.

Maksymowska, D., Richard, P., Piekarek-Jankowska, H., Riera, P., 2000. Chemical and isotopic composition of the organic matter sources in the Gulf of Gdansk (Southern Baltic Sea). Estuar. Coast. Shelf Sci. 51 (5), 585-598.

Martin, J.M., Zhang, J., Shi, M.C., Zhou, Q., 1993. Actual flux of the Huanghe (Yellow river) sediment to the Western Pacific ocean. Neth. J. Sea Res. 31 (3), 243-254.

Mayer, L.M., 1994. Surface area control of organic carbon accumulation in continental shelf sediments. Geochim. Cosmochim. Acta 58 (4), 1271-1284.

Mckinney, R.A., Nelson, W.G., Charpentier, M.A., Wigand, C., 2001. Ribbed mussel nitrogen isotope signatures reflect nitrogen sources in coastal salt marshes. Ecol. Appl. 11 (1), 203-214.

Meyers, P.A., 1997. Organic geochemical proxies of paleoceanographic, paleolimnologic, and paleoclimatic processes. Org. Geochem. 27 (5-6), 213-250.

Nielsen, L.P., Risgaard-Petersen, N., Fossing, H., Christensen, P.B., Sayama, M., 2010. Electric currents couple spatially separated biogeochemical processes in marine sediment. Nature 463 (7284), 1071-1074.

Owen, R.B., Lee, R., 2004. Human impacts on organic matter sedimentation in a proximal shelf setting, Hong Kong. Cont. Shelf Res. 24 (4), 583-602.

Pan, Y., Fan, W., Huang, T.H., Wang, S.L., Chen, C.T.A., 2015. Evaluation of the sinks and sources of atmospheric $\mathrm{CO}_{2}$ by artificial upwelling. Sci. Total Environ. 511, 692-702.

Pancost, R.D., Boot, C.S., 2004. The palaeoclimatic utility of terrestrial biomarkers in marine sediments. Mar. Chem. 92 (1), 239-261.

Paropkari, A.L., Babu, C.P., Mascarenhas, A., 1992. A critical evaluation of depositional parameters controlling the variability of organic carbon in Arabian Sea sediments. Mar. Geol. 107 (3), 213-220.

Paropkari, A.L., Babu, C.P., Mascarenhas, A., 1993. New evidence for enhanced preservation of organic carbon in contact with oxygen minimum zone on the western continental slope of India. Mar. Geol. 111 (1-2), 7-13.

Pedersen, G., Calvert, S.E., 1991. Anoxia vs. productivity: what controls the formation of organic-carbon-rich sediments and sedimentary rocks?: reply. AAPG Bull. 75 (3), 500-501.

Prahl, F., Small, L.F., Eversmeyer, B., 1997. Biogeochemical characterization of suspended particulate matter in the Columbia River Estuary. Mar. Ecol. Prog. Ser. 160 (1), 173-184.

Qiao, S.Q., Shi, X.F., Wang, G.Q., Yang, G., Hu, N.J., 2010. Discussion on grain-size characteristics of seafloor sediment and transport pattern in the Bohai Sea. Acta Oceanol. Sin. 32 (4), 139-147.

Qiu, Z., Yan, C., Zhao, Y., Du, M., 2011. The release and oxidation of ammonia at the sediment-water interface of Jiulong River Estuary wetland under different oxygen conditions. Ecol. Environ. Sci. 20 (12), 1902-1908.

Ramaswamy, V., Gaye, B., Shirodkar, P., Rao, P., Chivas, A., Wheeler, D., Thwin, S., 2008.
Distribution and sources of organic carbon, nitrogen and their isotopic signatures in sediments from the Ayeyarwady (Irrawaddy) continental shelf, northern Andaman Sea. Mar. Chem. 111 (3), 137-150.

Ransom, B., Kim, D., Kastner, M., Wainwright, S., 1998. Organic matter preservation on continental slopes: importance of mineralogy and surface area. Geochim. Cosmochim. Acta 62 (8), 1329-1345.

Reddy, K.R., Jessup, R.E., Rao, P.S.C., 1988. Nitrogen dynamics in a eutrophic lake sediment. Hydrobiologia 159 (2), 177-188.

Redfield, A.C., Ketchum, B.H., Richards, F.A., 1963. The influence of organisms on the composition of sea-water. In: Hill, M.N. (Ed.), The Sea: Ideas and Observations on Progress in the Study of the Seas, Volume 2: The Composition of Sea-Water: Comparative and Descriptive Oceanography. John Wiley \& Sons, Inc, New York, pp. 26-77.

Rumolo, P., Barra, M., Gherardi, S., Marsella, E., Sprovieri, M., 2011. Stable isotopes and $\mathrm{C} / \mathrm{N}$ ratios in marine sediments as a tool for discriminating anthropogenic impact. J. Environ. Monit. 13 (12), 3399-3408.

Rydin, E., 2000. Potentially mobile phosphorus in Lake Erken sediment. Water Res. 34 (7), 2037-2042.

Schubert, C.J., Calvert, S.E., 2001. Nitrogen and carbon isotopic composition of marine and terrestrial organic matter in Arctic Ocean sediments: implications for nutrient utilization and organic matter composition. Deep-Sea Res. Pt. I 48 (3), 789-810.

Schultz, P., Urban, N.R., 2008. Effects of bacterial dynamics on organic matter decomposition and nutrient release from sediments: a modeling study. Ecol. Model. 210 (1), $1-14$.

Sinkko, H., Lukkari, K., Sihvonen, L.M., Sivonen, K., Leivuori, M., Rantanen, M., Paulin, L., Lyra, C., 2013. Bacteria contribute to sediment nutrient release and reflect progressed eutrophication-driven hypoxia in an organic-rich continental sea. PLOS One 8 (6), 67061.

Thornton, S.F., Mcmanus, J., 1994. Application of organic carbon and nitrogen stable isotope and $\mathrm{C} / \mathrm{N}$ ratios as source indicators of organic matter provenance in estuarine systems: evidence from the Tay Estuary, Scotland. Estuar. Coast. Shelf Sci. 38 (3), 219-233.

Torres, I., Inglett, P., Brenner, M., Kenney, W., Ramesh Reddy, K., 2012. Stable isotope $\left(\delta^{13} \mathrm{C}\right.$ and $\left.\delta^{15} \mathrm{~N}\right)$ values of sediment organic matter in subtropical lakes of different trophic status. J. Paleolimnol. 47 (4), 693-706.

Van der Weijden, C.H., Reichart, G.J., Visser, H.J., 1999. Enhanced preservation of organic matter in sediments deposited within the oxygen minimum zone in the northeastern. Arab. Sea. Deep-Sea Res. Pt. I 46 (5), 807-830.

Vizzini, S., Mazzola, A., 2006. Sources and transfer of organic matter in food webs of a Mediterranean coastal environment: evidence for spatial variability. Estuar. Coast. Shelf Sci. 66 (3), 459-467.

Voss, M., Deutsch, B., Elmgren, R., Humborg, C., Kuuppo, P., Pastuszak, M., Rolff, C., Schulte, U., 2006. River biogeochemistry and source identification of nitrate by means of isotopic tracers in the Baltic Sea catchments. Biogeosciences 3 (4), 663-676.

Wang, B.D., Liu, F., Wang, G.Y., 1999. Horizontal distributions and seasonal variations of dissolved oxygen in the southern Huanghai Sea. Acta Oceanol. Sin. 21 (4), 47-53.

Wang, B.D., Wang, X.L., Zhan, R., 2003. Nutrient conditions in the Yellow Sea and the East China sea. Estuar. Coast. Shelf Sci. 58 (1), 127-136.

Wen, T.T., Zhang, C.S., Wang, L.S., Shi, X.Y., 2009. The horizontal distribution of biogenic elements in spring and autumn of North Yellow Sea. J. Ocean Univ. China 39 (4), 789-798.

Wu, Y., Zhang, J., Li, D.J., Wei, H., Lu, R.X., 2003. Isotope variability of particulate organic matter at the PN in the East China Sea. Biogeochemistry 65 (1), 31-49.

Yang, B., Cao, L., Liu, S.M., Zhang, G.S., 2015. Biogeochemistry of bulk organic matter and biogenic elements in surface sediments of the Yangtze River Estuary and adjacent sea. Mar. Pollut. Bull. 96 (1-2), 471-484.

Ye, L.L., Pan, C.R., Zhang, Z.Y., Zheng, Z.X., Liu, J.J., Wang, J.Q., 2006. Characteristics of $\mathrm{N}$ forms in Wabu Lake sediments and effects of environmental factors on $\mathrm{NH}_{4}{ }^{+}-\mathrm{N}$ release. J. Agro-Environ. Sci. 25 (5), 1333-1336.

Zhai, W.D., Zheng, N., Huo, C., Xu, Y., Zhao, H.D., Li, Y.W., Zang, K.P., Wang, J.Y., Xu, X.M., 2014. Subsurface $\mathrm{pH}$ and carbonate saturation state of aragonite on the Chinese side of the North Yellow Sea: seasonal variations and controls. Biogeosciences 11 (4), 1103-1123.

Zhang, J., Huang, W.W., Shi, M.C., 1990. Huanghe (Yellow River) and its estuary: sediment origin, transport and deposition. J. Hydrol. 120 (1), 203-223.

Zhang, R., Tang, J., Li, J., Zheng, Q., Liu, D., Chen, Y., Zou, Y., Chen, X., Luo, C., Zhang, G., 2013. Antibiotics in the offshore waters of the Bohai Sea and the Yellow Sea in China: occurrence, distribution and ecological risks. Environ. Pollut. 174 (5), 71-77.

Zhang, R.Y., Wu, F.C., Liu, C.Q., Fu, P.Q., Li, W., Wang, L.Y., Liao, H.Q., Guo, J.Y., 2008. Characteristics of organic phosphorus fractions in different trophic sediments of lakes from the middle and lower reaches of Yangtze River region and Southwestern Plateau, China. Environ. Pollut. 152 (2), 366-372.

Zhao, Q., Zang, L., Zhang, C.S., Shi, X.Y., 2012. The seasonal changes of nutrients and interfering factors in the west of the North Yellow Sea. Adv. Mar. Sci. 30 (1), 69-76.

Zhou, F.X., Gao, X.L., Yuan, H.M., Song, J.M., Chen, C.T.A., Lui, H.K., Zhang, Y., 2016. Geochemical forms and seasonal variations of phosphorus in surface sediments of the East China Sea shelf. J. Mar. Syst. 159, 41-54.

Zhou, F.X., Gao, X.L., Yuan, M.H., Song, J.M., Chen, F.J., 2018. The distribution and seasonal variations of sedimentary organic matter in the East China Sea shelf. Mar. Pollut. Bull. 129 (1), 163-171. 